\title{
A CONTRIBUIÇÃo dO BRASIL PARA A DESCOBERTA DE UM NOVO ELEMENTO QUÍMICO - O PALÁDIO
}

\author{
Luciano E. Faria ${ }^{\mathrm{a}, \mathrm{b},(1)}$ e Carlos A. L. Filgueiras ${ }^{\mathrm{a}, *}$ \\ ${ }^{a}$ Departamento de Química, Universidade Federal de Minas Gerais, 31270-901 Belo Horizonte - MG, Brasil \\ ${ }^{\mathrm{b} C e n t r o}$ Universitário Newton Paiva, 30494-230 Belo Horizonte - MG, Brasil
}

Recebido em 30/11/2018; aceito em 23/01/2019; publicado na web em 21/03/2019

\begin{abstract}
THE CONTRIBUTION OF BRAZIL TO THE DISCOVERY OF A NEW CHEMICAL ELEMENT - PALADIUM. In the year 2019 the periodic table of the elements will celebrate 150 years. A frequent misunderstanding says that palladium might have been initially discovered in samples from Brazil. Indeed it was found in the country in the early nineteenth century, but this discovery was preceded by other findings elsewhere in South America. This article will report its discovery, both abroad and in Brazil, as well as many other related aspects.
\end{abstract}

Keywords: palladium; discovery of new elements; early mining techniques.

\section{O PALÁDIO EM MINAS GERAIS E NO BRASIL}

O paládio $\left({ }_{46} \mathrm{Pd}^{106,4}\right)$ é um elemento químico cuja descoberta está relacionada à história da mineração em Minas Gerais. Esse metal teria sido anteriormente confundido com a platina ou mesmo nomeado como "ouro podre", quando era encontrado em certas proporções em ligas naturais de ouro aluvionar, extraído das areias de rios ou em minas profundas. Descoberto entre 1802-1803, atualmente esse metal apresenta enorme relevância em processos químicos e tecnológicos, pois é utilizado tanto como núcleo metálico de catalisadores químicos quanto na utilização em processos que envolvam armazenamento ou purificação de hidrogênio gasoso. Além dessas aplicações práticas, uma busca em periódicos disponíveis na base de dados do Web of Science - com a utilização do termo "palladium" - indica um grande número de citações em artigos científicos no século atual, que somaram mais de seis mil artigos em 2015 que, em grande parte, indicam sua utilização em sínteses orgânicas (30\% do total das citações) e físico-química (20\%).

Em aspectos tecnológicos, os Elementos ou Metais do Grupo da Platina (MGP), que são formados por platina (Pt), paládio ( $\mathrm{Pd})$, ródio $(\mathrm{Rh})$, irídio $(\mathrm{Ir})$, ósmio $(\mathrm{Os})$ e rutênio $(\mathrm{Ru})$, têm muito interesse comercial. Eles fazem parte dos componentes principais de conversores catalíticos automotivos, introduzidos em automóveis a partir da década de 70. A intenção de tais catalisadores é a redução da emissão de monóxido de carbono e hidrocarbonetos. ${ }^{1}$ Os MGP são elementos assim agrupados dada a sua metalogênese, ou seja, durante a sua concentração no solo por parte de emissões vulcânicas, ou da concentração e precipitação dos mesmos em solução que muitas vezes são precipitados juntos. Dentre eles, os dois elementos de maior interesse, a platina e o paládio, têm hoje em dia sua produção mundial concentrada em dois países, a África do Sul e a Rússia, com menores contribuições de produção pelo Canadá e EUA. ${ }^{2}$ Uma interessante comparação do preço desses dois metais pode ser obtido no portal ${ }^{3}$ da Johnson Matthey Precious Metal Management - instituição que ampara as atividades de pesquisa e comércio do mercado de MGP - que apresenta uma sessão específica para esse grupo de metais preciosos, cujo interesse comercial é regido por um grupo denominado London Platinum and Palladium Market (LPPM), que tem regulado os preços desses metais durante as últimas décadas.

Uma série de $\operatorname{artigos}^{4-7}$ propõe a forma com que foi depositado o

*e-mail: calfilgueiras@gmail.com paládio, além de outros metais mais nobres como a platina e o ouro, em uma faixa do estado de Minas Gerais. Ela compreende um alinhamento de $120 \mathrm{~km}$ no sentido sul-norte que se inicia no Quadrilátero Ferrífero (QF), ou mais exatamente nas cidades de Ouro Preto e Ouro Branco, e se encerra em Diamantina no coração da Serra do Espinhaço (Figura 1). Nesses artigos os autores dão evidências para a formação de finas camadas paladiadas em torno de pequenos grãos ou pepitas de ouro, a partir da movimentação do paládio em soluções salinas a baixas temperaturas, responsável pela precipitação do paládio, sugerindo a ocorrência de um processo não-magmático em ambientes oxidativos. Especificamente no Córrego Bom Sucesso, distrito da cidade do Serro, os autores apresentam análises de pepitas de platina paladiada e apresentam razões geológicas para o descobrimento de ouro, platina e paládio em terrenos quartzíticos, especificamente em veios de hematita.

No entanto a presença de paládio em ligas naturais com outros metais não é exclusividade de Minas Gerais. Na Bahia, mesmo antes da corrida do ouro iniciada no fim do século XVII em Minas, a existência de moedas de ouro cunhadas localmente e com variado teor de paládio permitiu a avaliação da circulação de metais preciosos na América Latina, além da identificação de amostras de ouro em moedas ou em barras produzidas entre 1694 a 1698 nas primeiras cunhagens realizadas no Brasil. ${ }^{8}$ Não se descarta ainda a possibilidade que o ouro produzido em Goiás, no mesmo período da descoberta do ouro em Minas, pudesse carregar em sua composição certa proporção em paládio. Isso porque ainda recentemente a descoberta de ligas naturais de ouro e paládio criou uma denominação, por parte dos garimpeiros atuais de outras partes do Brasil, ao "ouro que se quebra com facilidade" e que dessa forma pode ser fracionado com martelos: trata-se do "ouro bombril" de Serra Pelada (PA) que chega a ter nesse caso uma proporção superior a $9 \%$ de paládio. ${ }^{9}$

\section{TRABALHOS CIENTÍFICOS REALIZADOS PARA A PROSPECÇÃO DE PALÁDIO NO SÉCULO XX EM MINAS GERAIS}

As reservas de paládio, ou de suas ligas com outros metais nobres de Minas Gerais, chamaram atenção não apenas dos primeiros bandeirantes, naturalistas e exploradores que por aqui passaram. Elas também foram o alvo de estudos de importantes geólogos e mineralogistas do século passado como Eugen Hussak e Djalma Guimarães.

Franz Eugen Hussak (1846-1911) nasceu em Graz, na Áustria, e realizou seus primeiros estudos sob a tutela de Ferdinand Zirkel, 


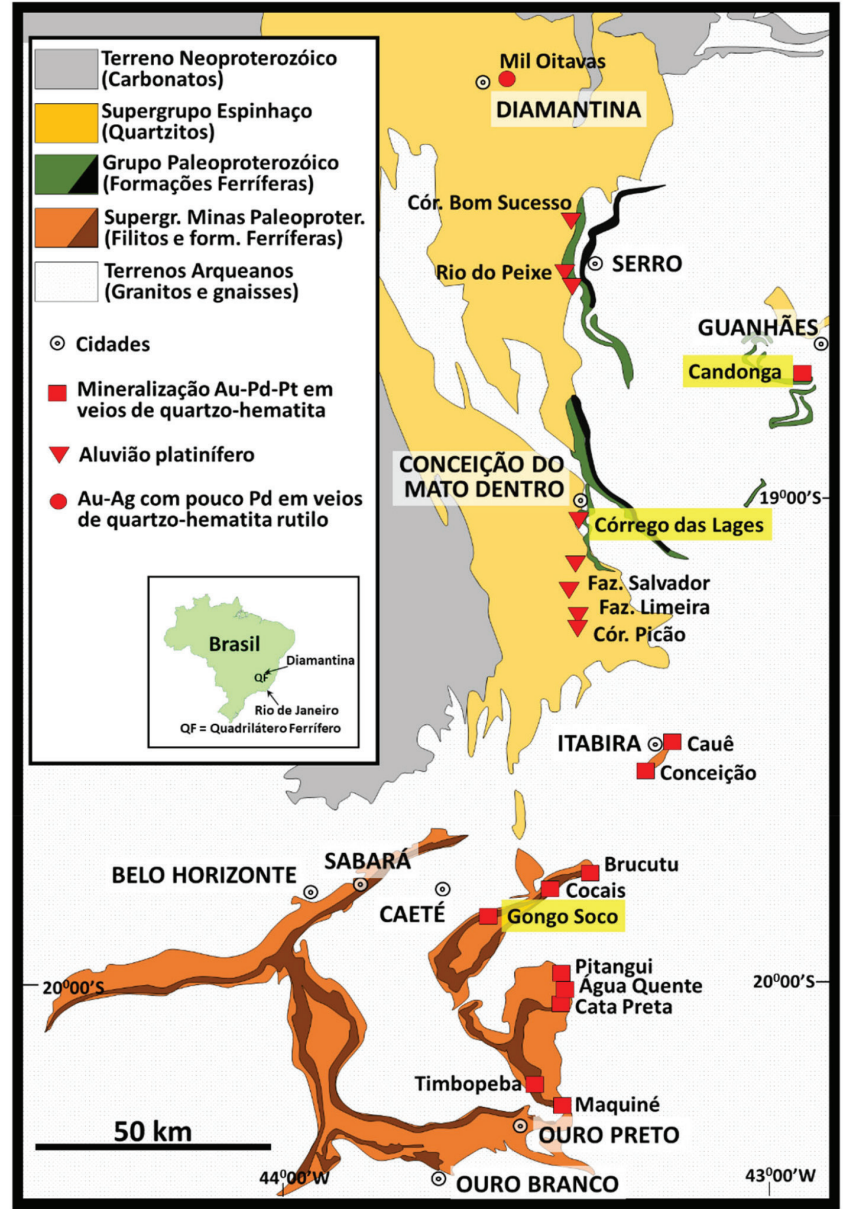

Figura 1. Cinturão Au-Pd platinífero de Minas Gerais (adaptado de Cabral et al., 2011) onde se destacam as minas de Gongo Soco, Candonga e o Córrego das Lages

um dos fundadores da petrografia em Leipzig, Alemanha. Mais tarde, ali mesmo, Hussak foi professor e escreveu livros que são até hoje referências na geologia (como o Anleitung zum Bestimmen der gesteinbildenden Mineralien ou 'Determinação dos minerais formadores de rochas', de 1884, além do Katechismus der Mineralogie, 1887) e material científico para periódicos. Sua obra mais relevante em relação ao paládio é "Über das Vorkommen von Palladium und Platin in Brasilien", ${ }^{10}$ apresentado à Academia de Ciências de Viena e publicada no boletim dessa instituição em 21 de abril de 1904. A obra foi traduzida para o português pelos irmãos Miguel e Manoel Arrojado Lisboa e foi publicada nos Annaes da Escola de Minas de Ouro Preto em 1906. ${ }^{11} \mathrm{O}$ texto original em alemão celebra um século da descoberta do paládio pelo químico e metalurgista inglês William Hyde Wollaston e reúne uma extensa bibliografia sobre o paládio e sua relação com o Brasil (que foram amplamente avaliados para este artigo).

Os estudos de Hussak foram favorecidos em parte por tais referências, além do acesso que teve a coleções de amostras auríferas que pôde encontrar na Europa no 'Imperial e Real Museu de História Natural de Vienna', que guarda minerais e demais produtos naturais brasileiros coletados por Emmanuel Pohl (1782-1834) e de uma grande coleção de amostras geológico-mineralógicas enviadas a Viena por Virgil von Helmreichen (1804-1852) em 1846. ${ }^{12}$ Hussak ainda conseguiu obter amostras de ouro paladiado das minas de Gongo Soco e Candonga (a primeira nas proximidades de Caeté, e a outra nos arredores de Guanhães, ambas cidades mineiras. Ver mapa da Figura 1). Sobre essa segunda mina, já esgotada à sua época, Hussak faz uma importante explanação da gênese dos veios em que se encontram o ouro e o paládio, além de análises minerais que indicavam o teor de $4,6 \%$ de ouro paladiado entre os abundantes silicatos e carbonatos da rocha matriz. Adicionando informações de Miguel Arrojado Lisboa (seu amigo, formado da Escola de Minas de Ouro Preto em 1894), ${ }^{13}$ além de citar fontes como Eschwege, Spix, Martius e Mawe, Hussak aponta ainda outros locais de ocorrência de paládio, platina ou de ligas de ouro com outros metais, respectivamente nas localidades de Itabira, Taquaril de Sabará, no Córrego das Lages de Conceição do Mato Dentro, do Serro (ver mapa da Figura 1) e do Rio Abaeté, todas essas localidades em Minas Gerais. Apontar quais seriam os locais onde o paládio e também a platina foram primeiramente localizadas na América do Sul facilitarão a compreensão sobre como o paládio foi descoberto.

Também mineralogista, Djalma Guimarães (1894-1973) nasceu em Santa Luzia e estudou na Escola de Minas de Ouro Preto, obtendo o título de Engenheiro Civil e de Minas em 1909. ${ }^{13}$ Petrologista e geoquímico, foi o principal responsável pela "descoberta das jazidas de apatita (fosfato) e do pirocloro (nióbio) de Araxá (MG), que fizeram do Brasil o maior produtor de nióbio do mundo". ${ }^{14}$ Seu estudo sobre o paládio e a platina é publicado como 'notas às margens' do que já havia sido divulgado por E. Hussak. ${ }^{15}$ Seu trabalho inicia em concordância com o geólogo austríaco a respeito da origem da platina existente nas regiões do Rio Abaeté, cujas propriedades "são características da que se atribue (sic) origem magmática; é, em parte, fortemente magnética e não contem paládio". Por outro lado, o problema oferecido pela origem da platina na Serra do Espinhaço contradizia aquilo que fora proposto por Hussak. Sobre essa discordância ele analisa um total de $400 \mathrm{~g}$ de grãos e pepitas de platina e paládio com aspectos análogos àqueles descritos pelo austríaco. A maior pepita pesava 18,91 g (Figura 2) com uma densidade igual a $15,37 \mathrm{~g} / \mathrm{cm}^{3}$, e além disso as maiores amostras apresentavam um envoltório ou crista com estrutura botrioidal, de coloração superficial amarela-suja ou parda e constituída quase inteiramente de platina; a parte interna ou núcleo é de paládio e platina, com predominância do primeiro metal. A massa paladiada, tem cor escura ou quase negra superficialmente e adquire polimento com certa facilidade, mas é de menor dureza que a crosta platinífera; esta dá ótimo polimento.

A densidade do paládio puro é $12,02 \mathrm{~g} / \mathrm{cm}^{3}$ enquanto a da platina é $21,45 \mathrm{~g} / \mathrm{cm}^{3}$, o que nos indica uma relação de $65 \%$ de Pd e $35 \%$ de Pt na pepita, caso consideremos apenas esses dois metais em sua composição. A coloração escura da amostra é atribuída à presença de

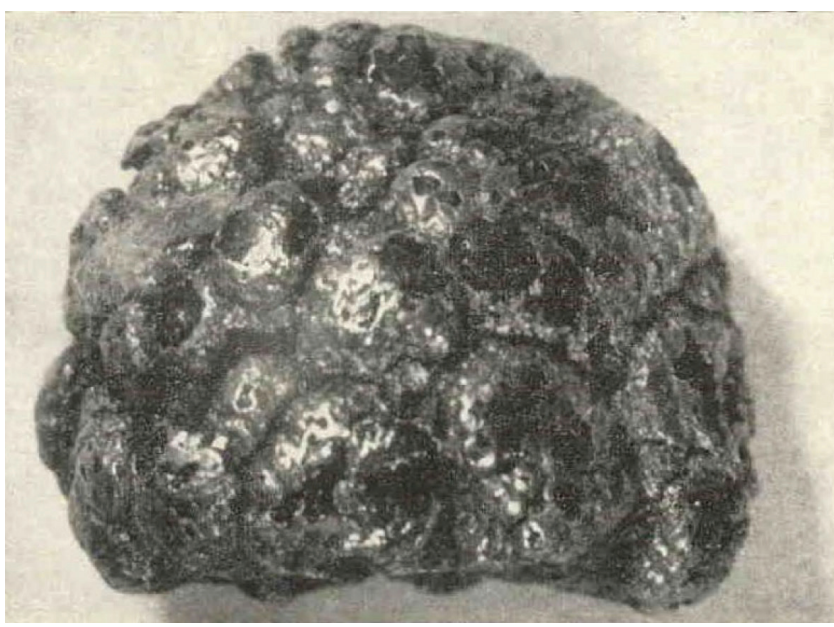

Figura 2. Pepita de platina-paládio da Fazenda Limeira, município do Morro do Pilar. Adaptado de Guimarães ${ }^{15}$ 
ferro e/ou manganês oxidados e que formavam apenas uma pequena camada sobre a superfície metálica.

\section{A DESCOBERTA DO PALÁDIO E AS PESQUISAS REALIZADAS PARA DETERMINAÇÃO DE SUA COMPOSIÇÃO EM MINERAIS E SUAS APLICAÇÕES}

A platina foi introduzida como um novo metal na Europa no século XVIII pelos espanhóis (cuja denominação nesse idioma é 'diminutivo de prata') e deve sua primeira descrição a Antonio de Ulloa (1716-1795), que após viajar pela América do Sul ${ }^{16}$ deu uma breve descrição do metal:

No distrito de Chocó (cuja localização atual é na Colômbia) existem muitas minas de Lavadero, ou ouro lavado, como aqueles que acabamos de descrever. Há também algum ouro, onde o mercúrio deve ser usado, que está envolvido em outros corpos metálicos, pedras e betumes. Várias minas foram abandonadas por causa da platina; uma substância de tal resistência, que, quando atingida em uma bigorna de aço, não é fácil separar-se, nem é calcinável; de modo que o metal encerrado dentro deste corpo obstinado não pode ser extraído sem trabalho e carga infinitos. ${ }^{17}$

A descoberta e as possibilidades do uso de um novo metal motivaram a procura por platina em demais países da América no fim do século XVIII por diversos naturalistas, enquanto na Europa do século XIX o foco era o uso desse metal para cunhagem de moedas e novos equipamentos científicos de precisão. Havia, no entanto, dificuldade em tornar a platina maleável, uma vez que as ligas naturais com outros metais a tornavam quebradiça. É nesse cenário que surge William Hyde Wollaston (1766-1828), originalmente médico, que se volta às ciências básicas com sucessos na área de análise química, ${ }^{18}$ na astronomia e na física. Além de muitas outras contribuições, ele foi autor de um processo de tornar maleável a 'platina' (sic; nos termos usados nessa época em inglês, "platina" era um mineral composto, na forma de liga natural com outros metais e "platinum" a platina purificada; nesse texto será usado o termo "minério de platina" para a liga). Wollaston trabalhou com a platina que era extraída na América do Sul, fato que the rendeu notoriedade e uma boa riqueza. ${ }^{19}$

A busca pela industrialização da platina metálica, produção de objetos e diversos testes com as ligas naturais eram realizados por Wollaston com um parceiro científico chamado Smithson Tennant (1761-1815). A dupla observou a precipitação de um pó escuro durante o tratamento do minério de platina com água-régia, que até então era nomeado por outros analistas como "plumbago", que na época era identificado como sendo grafita, óxido de molibdênio, galena ${ }^{20}$ ou ainda carbeto de ferro. Não é possível afirmar, através da leitura dos artigos do início do século XIX, que Wollaston e Tennant tivessem obtido a platina de outra procedência senão da América do Sul, mas pode-se acreditar que eles estivessem trabalhando no ano de 1802 com amostras de "grãos de platina, no estado impuro em que são originalmente encontradas". ${ }^{21}$ Outros autores indicam que o minério de platina foi extraído em Nueva Granada, atual Colômbia, e contrabandeada até Londres através de portos na Jamaica. ${ }^{22}$ Por sua vez, afirma-se ainda ${ }^{23}$ que a partir de meados do século XVIII, com a intensa demanda de platina por países como Inglaterra e França, o contrabando de diversos minerais foi comum e praticado diretamente entre Nueva Granada e Europa, de uma forma que o governo Espanhol não conseguia suprir legalmente. Há ainda um autor brasileiro que defende que o minério de platina do qual os novos elementos foram descobertos eram "oriundos do Córrego das Lages, no distrito de Morro do Pilar, Minas Gerais; e de Goiás". ${ }^{24}$

Os estudos de Wollaston e Tennant foram então divididos: enquanto Wollaston trabalhou com a parte do mineral de platina solubilizado em água-régia (Equação 1), Tennant lidou com a parte insolúvel, ou plumbago, no qual descreveu a descoberta de dois novos elementos químicos, o Irídio (Ir) e o Ósmio (Os). ${ }^{25}$

$$
\mathrm{Pt}(\mathrm{Pd} / \mathrm{Rh} / \mathrm{Os} / \mathrm{Ir})_{(\mathrm{s})}+\mathrm{HNO}_{3} / \mathrm{HCl}_{(\mathrm{aq})}
$$

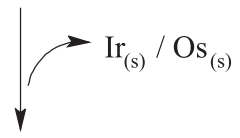

$$
\mathrm{H}_{2}\left[\mathrm{PtCl}_{6}\right]_{(\mathrm{aq})}+\mathrm{H}_{2}\left[\mathrm{PdCl}_{6}\right]_{(\mathrm{aq})}+\mathrm{RhCl}_{3(\mathrm{aq})}
$$

Wollaston publicou em 1804 nas Philosophical Transactions of the Royal Society of London a descoberta do Ródio (Rh) também existente na solução com a platina. ${ }^{26}$ A descoberta do Paládio, contido na mesma solução foi, no entanto, objeto de uma estranha forma de divulgação que gerou um episódio da História da Química denominado "a controvérsia Wollaston/Chenevix", um ano antes do anúncio da descoberta do ródio. Este fato revela não só a efervescente corrida pela descoberta de novos elementos no início do século XIX, em que se empenharam os cientistas da época, mas ainda a natureza e real definição da química dos novos elementos.

Acreditando que outros cientistas rivais pudessem atingir o mesmo objetivo e publicar a descoberta do paládio - mais especificamente os franceses Vauquelin e Fourcroy, que desenvolviam trabalhos semelhantes com platina em Paris -, Wollaston publicou um anúncio anônimo em abril de 1803 que foi enviado aos sócios da Royal Society em Londres, além de ser divulgado em panfletos e revistas na Inglaterra (Figura 3).

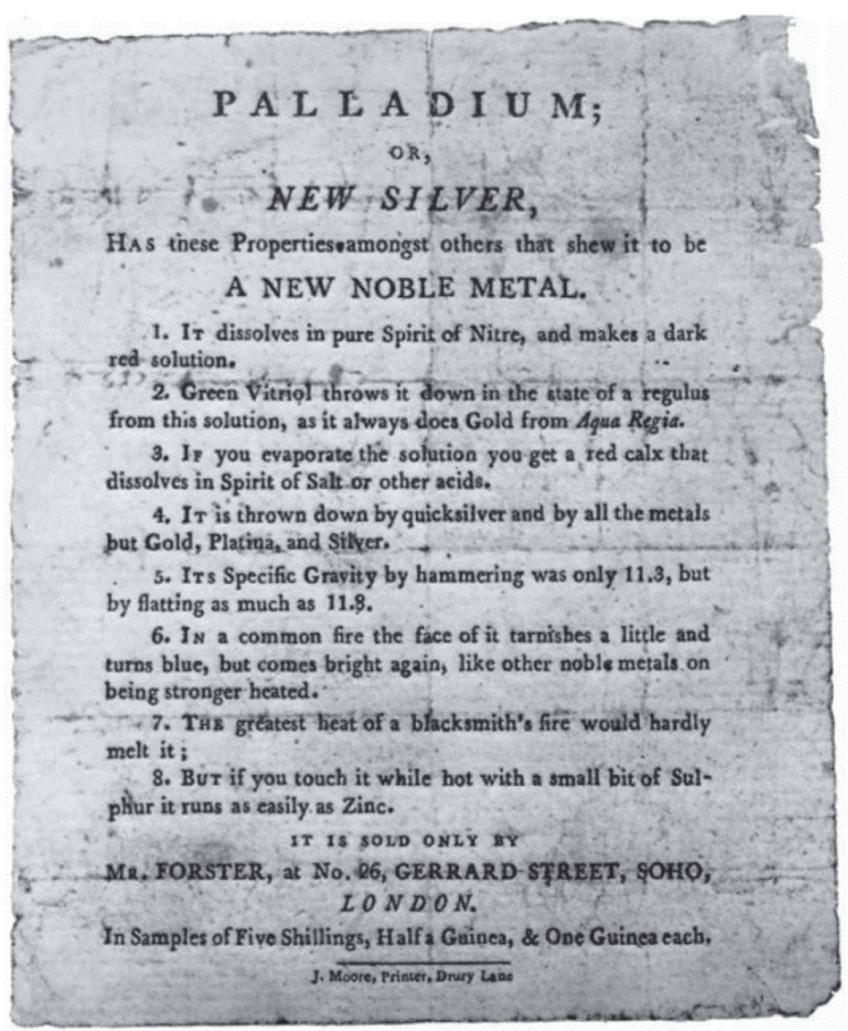

Figura 3. Panfleto distribuído aos sócios da Royal Society anunciando a venda da "nova prata" ou Paládio 27

No princípio, a publicação parece não ter gerado grande interesse da comunidade científica, mas despertou a curiosidade de um 
cientista irlandês, de origem francesa, Richard Chenevix (17661828). Chenevix, que da mesma forma que Wollaston, já havia divulgado artigos nas Philosophical Transactions que lhe trouxeram boa reputação como químico analítico. Enérgico e cheio de ímpeto, Chenevix trabalhou arduamente durante algumas semanas nas pequenas lâminas metálicas comercializadas do novo elemento que comprou do comerciante de minerais Jacob Forster. ${ }^{28}$ Seu trabalho foi lido na Royal Society em maio de 1803, e intitulado "Enquiries concerning the Nature of a metallic Substance lately sold in London, as a new Metal, under the Title of Palladium", ${ }^{29}$ ou a "Investigação da natureza de uma substância metálica recentemente vendida em Londres, como um novo metal, sob o título de Paládio". Nesse artigo ele afirma que o paládio que analisou seria um amálgama formado por platina e mercúrio. Além disso refuta a proposta de que mais um elemento químico deveria ser reconhecido e ataca o autor anônimo dos panfletos que versavam sobre a venda do metal:

Fomos informados de muitas extraordinárias anomalias nas afinidades químicas, pelo Sr. Berthollet; já o Sr. Hatchett nos fez conhecer algumas, não menos extraordinárias, nas propriedades das ligas. No entanto, penso que devemos deixar de nos perguntar o que foi relatado por esses químicos, quando aprendemos que o paládio não é, como foi anunciado vergonhosamente, um novo metal simples, mas uma liga de platina; e que a substância que pode assim mascarar as propriedades mais características desse metal, enquanto perde o maior número de propriedades, é o mercúrio. ${ }^{29}$

Claude L. Berthollet (1748-1822), citado por Chenevix, foi o químico francês responsável pela proposta da 'Afinidade Química', conceito relativo que explicava a composição química de alguns materiais e dos produtos de suas transformações. Ele foi um dos principais opositores da teoria atômica de Dalton. Charles Hatchett (1765-1847), também citado, foi um hábil químico e metalurgista britânico que propôs que cobre e prata seriam os melhores metais para formar ligas com o ouro em cunhagens sem que esse perdesse suas propriedades. ${ }^{30}$ Com esse fundo científico, Chenevix acreditou que "as propriedades químicas de platina e mercúrio eram tão alteradas pela sua combinação que o composto resultante teria sido erroneamente caracterizado como um novo elemento". Sua afirmação foi baseada através de suas inúmeras tentativas de sintetizar uma liga $\mathrm{Pt} / \mathrm{Hg}$ que apresentassem as mesmas características ilustradas no folheto e não pela análise direta da pequena amostra do novo metal comprado por ele.

Após a divulgação do trabalho de Chenevix, a resposta de Wollaston seria mais uma vez na forma de um anúncio anônimo em 1804 no Journal of Natural Philosophy, Chemistry, and Arts. ${ }^{31}$ Wollaston já havia publicado a descoberta do ródio nas Phil. Trans. e nesse mesmo artigo descreveu ainda, a partir da platina solubilizada, o possível isolamento do paládio puro, livre de qualquer etapa de purificação com o uso de mercúrio.$^{29}$ Esse segundo anuncio anônimo convidava os químicos e metalurgistas da época a produzir barras de paládio através do amálgama de platina e mercúrio da forma que Chenevix havia proposto. $\mathrm{O}$ vencedor seria aquele que obtivesse um material com as mesmas propriedades descritas no panfleto anterior. Entretanto, apesar de um prêmio de 20 libras (elevado valor para a época), o desafio parece não ter sido aceito por nenhum químico.

Um ano após o desafio, em 1805, em outro artigo ${ }^{32}$ Wollaston assume o descobrimento do paládio, ocorrido em 1802, durante seu trabalho com a platina. Ele explica que deu esse nome ao elemento em referência ao recém-descoberto planeta Pallas (mais tarde modificado para asteroide), também descoberto em 1802 por H. W. Olbers. Por parte de Chenevix mais um artigo foi publicado em 1805, tratando "Sobre a ação da platina e do mercúrio um sobre o outro", ${ }^{33}$ que não ganhou a mesma atenção de sua proposta para o que ele chamava a "síntese" do paládio. É certo que esse tipo de rivalidade científica deixou marcados tanto Wollaston quanto Chenevix por censuras e críticas dos demais membros e diretores conservadores da Royal Society.

Ainda no artigo de $1805,{ }^{32}$ Wollaston descreve a purificação da platina pela separação de chumbo, ferro e cobre que também apareciam em pequenas proporções no minério de platina. Ao tentar separar o cobre com ácido nítrico concentrado, uma cor marrom escura tomava forma ao invés do esperado azul ou esverdeado do nitrato de cobre (II). Isso provavelmente ocorreu porque o nitrato de paládio (II) obtido é um sólido marrom-avermelhado (Eq. 2). Como ouro e platina não reagem com ácido nítrico puro nem diluído, Wollaston indicou que teve "motivos para suspeitar da presença de um novo material, mas não estava totalmente satisfeito de sua existência até eu tentar a precipitação com mercúrio". Do amálgama obtido após o acréscimo do mercúrio (ou quicksilver, como se refere no panfleto) ele consegue isolar o paládio que "não podia ser fundido pelo maçarico" e cujo produto de reação, novamente feita com ácido nítrico, revelava outra vez a coloração avermelhada (Eq. 2). Dessa solução não era possível a precipitação pela adição de sal amoníaco (reação específica de identificação dos nitratos de platina) nem por adição de maior concentração de nitratos. Por outro lado, um sólido amarelo era obtido através da reação dessa solução avermelhada com o prussiato de potássio, $\mathrm{K}_{4} \mathrm{Fe}(\mathrm{CN})_{6}$, na possível conversão a $\mathrm{Pd}(\mathrm{CN})_{2}$ (Eq. 3).

$$
\begin{aligned}
& \mathrm{Pd}_{(\mathrm{s})}+4 \mathrm{HNO}_{3(\mathrm{l})} \rightarrow \mathrm{Pd}\left(\mathrm{NO}_{3}\right)_{2(\mathrm{aq})}+2 \mathrm{NO}_{2(\mathrm{~g})}+2 \mathrm{H}_{2} \mathrm{O}_{(\mathrm{l})} \\
& \mathrm{Pd}\left(\mathrm{NO}_{3}\right)_{2(\mathrm{aq})}+\mathrm{K}_{4} \mathrm{Fe}(\mathrm{CN})_{6(\mathrm{aq})} \rightarrow \mathrm{Pd}(\mathrm{CN})_{2(\mathrm{~s})}+\mathrm{Fe}\left(\mathrm{NO}_{3}\right)_{2(\mathrm{aq})}+4 \mathrm{KCN}_{(\mathrm{aq})}
\end{aligned}
$$

Ainda, a partir de uma mistura de 5 partes de ácido muriático (ou clorídrico), cinco partes de água e uma parte de salitre $\left(\mathrm{KNO}_{3}\right)$, Wollaston conseguiu obter um "solvente" que separava todo o paládio e pequenas partes de platina de seu minério. Dessa forma ele obtinha mais uma vez cristais de coloração avermelhada que apresentavam um contraste de coloração, variando entre o vermelho e o verde dependendo do ângulo de visão. Essa descrição está de acordo com as três primeiras propriedades anunciadas no panfleto, onde "spirit of nitre" (espírito do nitro) é o ácido nítrico, "spirit of salt" (espírito do cloreto de sódio) o ácido clorídrico e o "green vitriol" (vitríolo verde) - sulfato de ferro (II), que é usado como agente redutor e precipita os sais de paládio "como acontece com o ouro em água régia". No entanto, Wollaston dá mais destaque ao método de precipitação do paládio por meio da utilização do prussiato, ou cianeto, de mercúrio (II), $\mathrm{Hg}(\mathrm{CN})_{2}$. Esse teste serviria tanto na indicação da presença de paládio quanto para a sua separação de outros metais menos nobres como cobre e ferro, pela produção do cianeto de paládio (II), que se precipita, e ao ser aquecido produzia o metal com grande pureza. Essa técnica foi notabilizada com a publicação do livro "System of Theoretical and practical Chemistry" de Friedrich Accum em 1808. ${ }^{34}$

$\mathrm{O}$ artigo que relaciona o paládio ao Brasil, também escrito por Wollaston, é publicado nas Philosophical Transactions em janeiro de 1809 sob o título "On platina and native palladium from Brazil" ${ }^{35}$ Além da presença do minério de platina nas referidas províncias espanholas da América e da descoberta de pequenas proporções de platina em ligas de prata da Espanha, feita por Vauquelin, Wollaston afirma que A amostra que estou a ponto de descrever agora é derivada de uma terceira fonte, e é mais interessante ao ter misturados grãos de paládio nativo. Este novo mineral foi recebido das minas de ouro no Brasil, por S. Exa. Cav. de Souza Coutinho, embaixador da corte de Portugal, residente neste país, $e$ espero que algum relato a respeito dele seja aceitável pela Royal Society, embora a análise tenha sido necessariamente imperfeita, a partir da pequena quantidade a que meus experimentos foram inevitavelmente confinados. 
O embaixador citado por Wollaston deve se tratar de Domingos Antônio de Sousa Coutinho (1760-1833), Conde e Marquês de Funchal e irmão de Rodrigo de Souza Coutinho. Ele também foi sócio da Academia das Ciências de Lisboa e financiou em Londres o lançamento do periódico "O Investigador Português em Inglaterra" para rivalizar com o "Correio Braziliense", esse de ideais liberais e ambos publicados em Londres. Souza Coutinho havia sido nomeado Ministro em Londres nos meados de $1802^{36} \mathrm{e}$ atuou politicamente na Grã-Bretanha durante o conturbado período político compreendido entre 1803 a $1814 .{ }^{37} \mathrm{O}$ embaixador reservara para si parte da amostra e concedeu a Wollaston uma pequena parcela para suas análises químicas. Wollaston continua seu artigo descrevendo que

O aspecto geral deste espécime é tão diferente do minério comum da platina, que eu não poderia formar nenhuma conjectura sobre os componentes que poderiam ser encontrados. Sua aparência era tal que à primeira vista induziria a suspeita de não estar no estado natural, pois tinha expressiva forma esponjosa que é dada à platina por tentativas imperfeitas de torná-la maleável através do uso do arsênico. Uma circunstância, no entanto, ocasiona uma presunção de que nenhuma arte tenha sido empregada para dar aos grãos sua aparência atual; uma vez que, após uma inspeção minuciosa, muitas pequenas partículas de ouro são discerníveis, mas não existe nenhuma areia magnética de ferro com as quais o minério peruano abunda, nem nenhum dos pequenos jacintos, que eu anteriormente notara como presas a esse mineral ${ }^{35}$

Sua análise inicial apontou a ausência de ferro ou de ródio na amostra, que eram frequentes componentes do minério de platina de Chocó. A amostra foi então tratada com água régia (ou como ele escreve, nitro-muriatic acid) de forma a dissolver os componentes do mineral. $\mathrm{O}$ que mais chamou a atenção do inglês foi o rápido ataque da água-régia a dois visíveis grãos presentes na amostra e que resultavam em uma solução de coloração avermelhada. Os grãos foram retirados e lavados para posterior análise que então, sob ação de ácido nítrico puro, "revelou uma profunda coloração vermelha, que, pelos testes de prussiato de mercúrio e de sulfato verde de ferro, pôde me satisfazer com o aparecimento do paládio".

Wollaston retornaria a Souza Coutinho para analisar o restante da amostra mineral e nela percebeu formas radiais e fibrosas que partiam de um ponto específico. É provável que uma imagem dessa amostra tenha sido utilizada para ilustrar o "Exotic Mineralogy" de James Sowerby, ${ }^{38}$ publicado em 1811 (Figura 4).

A descrição dessa imagem traz o seguinte texto de Sowerby: O paládio nativo, quase puro, é encontrado intercalado entre a platina brasileira, da qual é distinguível pela aparência rugosa dos grãos, que, em um exame mais minucioso, apresentam uma forma arbórea ou ramificada. Na cor, dificilmente são diferentes. É um pouco mais duro que oferro, muito maleável e, em comum com os outros metais novos encontrados na platina, é quase infusível. Foi descoberto pelo Dr. Wollaston, que gentilmente me permitiu desenhar seus espécimes, que talvez sejam os únicos que jamais tenham sido preservados. A história deste novo metal é bem conhecida para relatar em maior detalhe aqui. ${ }^{38}$

A partir daí Wollaston adiantava à comunidade científica algumas informações que ainda foram questionadas no mesmo ano por outra publicação de autoria de John Murray (1778-1820). Murray era um jovem "filósofo químico" que fazia parte da Royal Society of Edimburgh ${ }^{39} \mathrm{e}$ que publicou o livro A System of Chemistry, em 4 volumes, em $1809 .{ }^{40}$ No livro ele dá destaque aos "metais e suas combinações" e inclui cinco

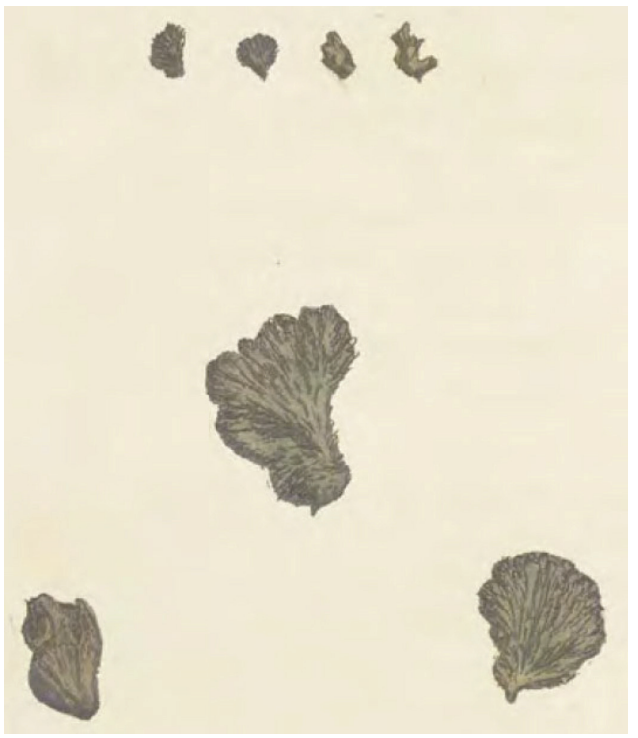

Figura 4. Imagem ilustrativa do "Paládio nativo" com as figuras inferiores ampliadas (sem escalas no original) ${ }^{38}$

dos MGP em seu trabalho. Utilizando em maior parte as informações sobre o paládio que foram publicadas por Chenevix, Murray levanta novamente a controvérsia criada pelos eventos. A densidade do paládio indicada no primeiro panfleto anônimo de Wollaston, com valores entre 11,3 e 11,8 (sem uso de unidades) não corresponde a uma origem a partir de ligas formadas entre platina $\left(\mathrm{d}=21,45 \mathrm{~g} / \mathrm{cm}^{3}\right)$ e mercúrio $(\mathrm{d}=$ $13,55 \mathrm{~g} / \mathrm{cm}^{3}$ ), a não ser que, de acordo com Murray, o "arranjo cristalino peculiar em que as novas substâncias podem estar dispostas a assumir, ou a partir da sua mudança de forma, a sua gravidade específica pode ser inferior à da média." Mais uma vez existe concordância por parte de Murray com a proposta das afinidades elementares como responsável pelas propriedades de novas substâncias. No fim do texto sobre o paládio, Murray concorda com a existência do novo elemento proposta por Wollaston, como mais uma nova substância simples. Murray ainda aponta que "a delicadeza e a precisão dos métodos de análise química moderna" alcançaram a avançada capacidade de identificar pequenas frações elementares em misturas como aquelas presentes em ligas naturais, uma vez que a proporção dos metais irídio, ródio, ósmio ou paládio na platina sul-americana não passava de "uma duodécima parte". Ele, no entanto, ainda apresenta dúvidas sobre a possibilidade de não serem esses outros metais já conhecidos, "uma vez que não é impossível que sejam ligas de outros; ou que as propriedades peculiares que parecem exibir possam surgir de combinações que a análise não detectou". Essa informação aumenta ainda mais a importância da descoberta do paládio em forma nativa no Brasil uma vez que, estando puro, o achado eliminaria as dúvidas que supusessem características de substâncias simples às ligas metálicas que apresentassem o paládio com outros componentes.

Ainda em 1809, nos Estados Unidos, o fundidor-chefe da Casa da Moeda de Filadélfia, químico e também responsável pelo refino de metais para cunhagem, Joseph Cloud (1770-1845), publicou nas Transactions of the American Philosophical Society um artigo em que analisava barras de ouro brasileiras. ${ }^{41}$ Cloud recebera cerca de 120 pequenos lingotes de ouro originados do Brasil, com uma massa total que variava entre 22,6 a $23,3 \mathrm{~kg}$. Os lingotes eram marcados em um dos lados com as armas de Portugal, e a inscrição do 'Rio das Mortes'. O outro lado foi marcado com suas respectivas qualidades. Dentre elas estavam duas ou três barras, de tal notável diferença em suas cores para qualquer outro tipo de ligas nativas de ouro que fui motivado a reservar uma delas, pesando 3 onças, 11 dwts. 12 grãos, para análises. 
Ele realizou cinco diferentes experimentos com a última barra descrita (de massa aproximada a 103g), submetendo uma certa porção à ação da água-régia (nitro-muriatic acid) que não deixou traços de sólidos perceptíveis no ensaio. Fundiu 24 quilates $(4,8 \mathrm{~g})$ de outra parte da mesma barra juntamente com prata na esperança de eliminar, em um cadinho sob a ação de atmosfera oxidante, metais que fossem menos nobres. No final dessa análise, no entanto, não houve redução da massa total após o processo. Esse material fundido com prata foi submetido a um laminador e depois ao ácido nítrico puro para se dissolver a prata presente. O resultado foi o aparecimento de uma coloração castanho-avermelhada na solução e um metal que não foi atacado pelo $\mathrm{HNO}_{3}$, "com aparência de ouro puro", pesando 22 quilates e 11/2 grãos (igual a $4,5 \mathrm{~g}$ o que indica $6,3 \%$ de outros elementos na composição da barra). O resíduo sólido, por sua vez, foi submetido à ação da água-régia e a solução obtida foi analisada para a presença de platina, com adição de cloreto de amônio, o que não surtiu nenhum resultado. No último experimento, Cloud tratou a solução obtida do tratamento dos 24 quilates com o ácido nítrico, e adicionou ácido clorídrico suficiente para a precipitação da prata na forma de cloreto, no entanto, sem a precipitação do material que corava a solução de vermelho.

Ao final, Cloud atacou toda a barra que originalmente pesava 103 g com ácido nítrico, tratando dessa vez a solução resultante com carbonato de potássio, da qual obteve um precipitado alaranjado em flocos que foi copelado para gerar um botão que julgou ser de paládio. Para confirmar sua observação, o analista separou o paládio de amostras de minério de platina pelo método descrito por Wollaston para propor comparações entre o que obtivera do ouro brasileiro. Como todos os resultados dos testes foram idênticos ao do inglês, Cloud concluiu:

Para mim foi suficientemente mostrado, e eu confio com satisfação, que o paládio tem uma existência real; que é um dos metais puros ou inoxidáveis; e, desta forma, pareia-se com ouro, prata e platina; e que foi encontrado em uma combinação nativa com ouro; sem a presença de platina, ou qualquer outro metal. ${ }^{41}$

Tais análises e experimentos de Wollaston e Cloud são mencionadas por Adolf F. Gehlen (1775-1815), um dos editores do Journal für Chemie und Physik de Schweigger, no qual ele publicou em 1811 o artigo "Platinum und Palladium in Brasilien und St. Domingo gefunden"42 ("Platina e Paládio encontrados no Brasil e em Santo Domingo") que traz ainda a análise do minério de platina paladiada encontrado próximo à cidade de Santo Domingo, atual República Dominicana, que foi publicada por Vauquelin em 1810 e tida como sendo idêntica à encontrada no Peru.

Em 1812, outro inglês descreveu tentativas de dissolver, com ácido nítrico, ligas contendo diferentes proporções de platina, ouro e prata. Percival N. Johnson (1792-1866) - fundador da já citada Johnson Mathey e já aos 19 anos um exímio ensaísta, indica que por causa da presença de paládio em moedas cunhadas no Brasil, essas chegavam até mesmo a ser desprezadas no mercado europeu. Segundo Johnson, encontrava-se $\mathrm{e}^{43}$

paládio geralmente compondo ligas com o ouro brasileiro, de forma que muitas vezes altera sua cor. Nós observamos particularmente na moeda do Brasil, muitas das quais foram rejeitadas à primeira vista, suspeitando que elas fossem falsificadas. Descobrimos há pouco tempo que, em uma barra do Brasil, a proporção chegava a quase 20 por cento, alterando a cor do mesmo a quase a cor do metal paládio.

A partir de 1817, Johnson iniciou um processo no qual conseguia extrair das barras e moedas de ouro vindas do Brasil o paládio de sua composição, que além de fornecer o metal em estado puro, deixava o ouro com aspecto mais original. Seu processo foi mantido em sigilo até que se candidatou à Royal Society em 1846, quando concordou em descrever sua metodologia. Ele empregava um processo semelhante ao de Cloud ao fundir o ouro com prata, separar o ouro dessa liga com o uso de ácido nítrico e depois precipitava a prata com cloreto de sódio e reduzia o paládio com zinco metálico. Reagia outra vez o paládio com ácido nítrico que era novamente precipitado com o acréscimo de cloreto de amônio que, ao ser aquecido, gerava o paládio puro. ${ }^{44}$ Após obter relevantes quantidades de paládio, principalmente separado do ouro obtido nas minas de Gongo Soco e Candonga que na época eram de propriedade de ingleses instalados em Minas Gerais -, Johnson propôs aplicações ao metal para proteção de objetos de prata, para a construção de instrumentos e uso como implantes odontológicos, finalidades em que até hoje se emprega o paládio. Essa técnica foi mais tarde publicada por Jean L. Lassaigne (1800-1859) no Journal de Chimie Médicale, em 1842, sem fazer referências sobre em qual parte do Brasil haviam sido obtidas as amostras de "paládio das areias auríferas" que eram submetidas ao método. ${ }^{45}$

Amostras de minério de ouro também chamaram a atenção dos alemães Wilhelm A. Lampadius (1772-1842), cujo talento em análises químicas de minerais o fizeram professor na Academia de Mineração de Freiberg dirigida por Werner, ${ }^{46}$ e Platnner (o artigo original ${ }^{47}$ indica seu nome como G. P. Platnner, no entanto somente foi encontrada a biografia de "Karl Friedrich Platnner" nascido em 1800 e falecido em 1858, que foi um grande metalurgista que realizou diversos ensaios com ouro). ${ }^{48}$ Lampadius e Platnner examinaram em suas habilidades, com análises químicas e utilização de maçarico, uma amostra recebida dos arredores de Sabará ou de Vila Rica. Dessa forma os alemães puderam indicar que a platina não formava ligas com o ouro e que esse poderia ser escurecido pela presença de dióxido de platina $\left(\mathrm{PtO}_{2}\right)$, óxido de cor extremamente negra, e assim a associação dos materiais seria responsáveis pela coloração do "ouro preto" encontrado nessas regiões. ${ }^{49}$ Além disso, sua análise química indicava:

calculado em 100 partes em peso:

$\begin{array}{lr}\text { Ouro .............. } & 52,95 \\ \text { Platina......... } & 30,60 \\ \text { Prata............ } & 9,52 \\ \text { Irídio............. } & \frac{1,42}{94,49}\end{array}$

Para a percentagem que falta a) certamente a presença de ósmio; b) traços de ferro; c) provavelmente ródio; d) paládio.

O óxido de paládio II (PdO), que provavelmente estava compondo os demais $5,51 \%$ da análise, também apresenta coloração escura e estava presente, mesmo que em frações reduzidas, no tão famoso ouro preto.

Passaram-se mais de 20 anos para que outro trabalho associasse o paládio ao Brasil. Jöns J. Berzelius (1779-1848) publicou em seu JahresBericht über die Fortschritte der physischen Wissenschaften ${ }^{50}$ uma descrição sobre alguns novos minerais recém descobertos que lhe foram enviados para análise química. Berzelius foi um dos mais notáveis químicos suecos do século XIX, que apoiou e deu subsídios para a Teoria Atômica proposta por Dalton. ${ }^{51} \mathrm{O}$ trecho que aborda a presença do paládio informa que

Sob o nome Ouro Poudre (sic) E. Pohl me enviou uma espécie de ouro sólido, que ocorre na Capitania de Porpez na América do Sul. Este ouro forma grãos poligonais de uma cor de ouro impuro, que derreteu sob ação do maçarico, com pequenos grãos de quartzo emergentes na superfície. Fundido com bórax, a bola de metal não muda de cor e é flexível após o resfriamento. Depois de subtrair os grãos de quartzo concentrados, cuja quantidade é muito pequena, esse ouro consiste, de acordo com minha própria análise em 0,623 
grm, de grãos pesados, de ouro 85,98, de paládio 9,85 e de prata 4,17. Não havia vestígios de cobre. ${ }^{50}$

Emmanuel Pohl, anteriormente comentado, enviou para museus da Europa uma enorme coleção de minerais do Brasil, principalmente de Mato Grosso e Goiás. Ele descreve esse mesmo "ouro podre", anunciado por Berzelius:

Por aquele tempo foi também descoberta Arraias, uma das mais ricas jazidas de ouro. Devido à feia cor acinzentada do minério ali achado, que aliás era muito bom, recebeu a jazida o nome Descoberto do Ouro Podre (p. 136) ... Essa cor parece indicar uma mistura de ouro com a platina (p. 277). ${ }^{52}$

Arraias atualmente é uma cidade do estado de Tocantins que na época pertencia à "Capitania de Goyaz". Quando associamos as informações dos dois textos acima, de Berzelius e de Pohl, podemos compreender o nome "Porpezita" que é dado ao mineral composto de paládio e ouro que foi analisado por Berzelius. A porpezita ilustra alguns livros e bancos de dados atuais sobre minerais. ${ }^{53,54}$ Essa corruptela para o nome do mineral, baseada no seu local de coleta, foi criada por Berzelius a partir da interpretação do nome "Goyaz" como sendo "Porpez", provavelmente influenciado pela grafia errônea de Pohl. ${ }^{55}$ Ainda é possível que o nome porpezita derive de Pompéu, uma antiga mina de ouro e hoje um distrito de Sabará.

Outra referência ao paládio que era encontrado junto ao ouro das minas de Gongo Soco e Candonga é feita novamente por Lampadius que recebeu amostras diversas de seu amigo, Percival Johnson. O primeiro pôde assim analisar, seguindo as anotações do inglês, não só o metal já separado, mas também a liga de ouro paladiado, o sal duplo de paládio (sic: Palladdoppelsalz) e amostras da "Zacotinga" (originalmente jacutinga). ${ }^{56} \mathrm{Em}$ seu trabalho, o alemão afirma que a separação do paládio puro a partir do aquecimento de seu sal duplo provavelmente o nitrato de tetra-aminopaládio (II), $\mathrm{Pd}\left(\mathrm{NH}_{3}\right)_{4}\left(\mathrm{NO}_{3}\right)_{2}$, um precipitado amarelo - seria mais fácil do que a obtenção do paládio por aquecimento de seu cianeto, conforme informaram Wollaston e Berzelius.

Mais um alemão contribuiu com estudos do paládio encontrado nas areias auríferas do Brasil, especificamente, do Córrego das Lages, situado em Morro do Pilar. Ele foi Gustav Rose, um mineralogista e petrologista. ${ }^{57} \mathrm{Em}$ um artigo ${ }^{58}$ ele trata do dimorfismo - ocorrência de cristais em diferentes formas - dos cristais de paládio em que se comporta como o irídio; não é apenas dimórfico, e pode, por circunstâncias, assumir formas hexaédricas ou de barras de seis lados, e ainda, uma vez que estas duas formas concordam com as do irídio, isodimorficas com ela. Já conhecemos dois metais que são dimórficos.

Ainda no século XIX, o periódico inglês "The Chemical News and Journal of Physical Science" de 1882 faz a associação da presença de ouro paladiado nas proximidades da cidade de Sabará, na região de Taquaril (hoje um bairro da capital mineira) por W. H. Seamon:

Parece que o ouro nativo combinado com paládio ("ouro preto"), que era antes coletado em quantidade considerável no Brasil, é agora raramente recebido na Casa da Moeda do Rio de Janeiro, sendo simplesmente lavado dos cascalhos de rios em pequena escala pelos trabalhadores pobres e em pequena escala. Estou em divida com o Prof. Orville A. Derby, Diretor da Pesquisa Geológica do Brasil, pelo trabalho em me fornecer um bom exemplar desta liga no distrito em que ocorre. $O$ ouro é finamente dividido, muito dele na forma de ouro em pó, os grãos de maior tamanho têm aspecto de lâminas. Tem a característica cor escura ou de bronze, devido à presença do paládio. ${ }^{59}$
Seamon indica que proporções dos componentes dessa amostra de "ouro preto" obtida por Derby seriam de:

Análise do "ouro preto"
Ouro ............. 91,06
Paládio ........... 8,21
Prata.......... Traços.
Ferro.......... Traços.
Total............. 99,27

Gravidade específica, 15,73. O ferro foi considerado um aderente mecânico. Quando calculada, a fórmula é $P d A u_{6}{ }^{60}$

Outras referências sobre o paládio podem ser encontradas em periódicos europeus e americanos, no entanto sem associar sua descoberta ao Brasil.

\section{AS PRIMEIRAS REFERÊNCIAS SOBRE O PALÁDIO FEITAS EM PORTUGUÊS NO SÉCULO XIX}

Em Portugal, o início do século XIX foi marcado pelas invasões francesas e a consequente vinda da Corte para o Brasil. Durante esse período, as publicações produzidas, fossem literárias, políticas ou científicas, eram muito escassas e aquilo que saiu à luz, voltado à divulgação das artes e ciências, tinha seus editores e imprensas situados em grandes metrópoles europeias. Esse tipo de publicações, denominados "Periódicos Portugueses de Emigração", ${ }^{61}$ apresentavam conteúdos científicos

publicados por portugueses residentes em Londres e em Paris, entre 1808 e 1822. Ao longo deste período, existiram nestas duas capitais comunidades de portugueses que, por diversos motivos, muitos deles relacionados com problemas políticos e religiosos, se tinham visto forçados a emigrar. Alguns deles, tendo verificado a importância da imprensa e compreendido o impacto que as novas ideias poderiam ter em Portugal, decidiram publicar periódicos redigidos em língua portuguesa, destinados a Portugal e aos seus domínios.

Nem a descoberta do paládio no minério de platina da América Espanhola, nem mesmo a do paládio nativo descrito por Wollaston em 1809 de amostras brasileiras, parecem ter tido repercussão em quaisquer textos dos periódicos portugueses de emigração. Isso se atribui ao fato de que descobertas na área de química não ganhavam destaque, devido ao pouco conhecimento científico dos editores dos jornais que apenas faziam menção a poucas e isoladas descobertas. Além disso, apenas curiosos fatos científicos surtiam interesse aos leitores dos periódicos, sem maiores referências a trabalhos anteriores.

No entanto, o descobridor do paládio é citado em dois artigos de 1813 no periódico "Correio Braziliense" - produzido em Londres a partir de 1808 pelo jornalista brasileiro Hipólito José da Costa. Esse periódico tinha como fonte algumas publicações relativas às ciências e artes da Inglaterra, que eram resumidas e traduzidas para o português. O primeiro artigo abordava um dos inventos de Wollaston, o aparato de "gellar, a que chama de Chryophorus" e sobre a análise química feita pelo inglês em cálculos renais. ${ }^{62}$ Já um outro artigo versava sobre sua leitura dos equivalentes atômicos de elementos feita na Royal Society. ${ }^{63}$

Da mesma forma que o Correio Braziliense, "O Investigador Português em Inglaterra", também editado e produzido em Londres, traduzia artigos publicados tanto na Grã-Bretanha quanto no continente europeu. Nesse jornal o paládio é citado em diversos números e volumes, no entanto, apenas relacionando fatos sobre suas propriedades, nomenclatura e classificação frente a outros elementos, essa última o maior desafio dos químicos da época. Uma proposta feita por André-Marie Ampère (1775-1836), presente nesse jornal, alinhou 
os elementos químicos de acordo com suas propriedades. Apesar de apenas 48 elementos serem conhecidos naquela época, Ampère tentou ajustá-los em 15 grupos (dentre gêneros e classes) em que associou com sucesso os metais alcalinos, os metais alcalino-terrosos e os halogênios. O paládio, nessa classificação, pertencia ao grupo dos Chrysides ou "metaes, que não soffrem a menor alteração no ar, seja qual for a temperatura, em que este se ache". ${ }^{64}$

No volume XXI de 1818, um artigo d'O Investigador dá imensa atenção ao sistema mineralógico estabelecido por Berzelius (ou Berzélio, como retratado no texto) que trazia todos os elementos conhecidos até então e que compunham substâncias inorgânicas. Para ele, as propriedades intrínsecas dos minerais só poderiam ser realmente conhecidas a partir do estudo de seus elementos constituintes. Nesse trabalho destaca-se

um sistema de classificação dos minerais, segundo o qual estes eram entendidos como compostos químicos de um núcleo restrito de constituintes minerais: terras, ácidos, álcalis, metais e corpos inflamáveis. Descreveu os minerais como sendo compostos químicos destas substâncias e definiu géneros e espécies apenas a partir da sua composição. ${ }^{61}$

Dentro dessa classificação, a tradução do Investigador traz a "Ordem III - Metaes Eletro-positivos" ${ }^{65}$ como sendo:

Metaes, cujas oxides fazem antes as vezes de bases, do que d'acidos.

Divisão $1^{a}$-Metaes, cujas oxides, misturadas com o carvão de lenha em pó, ou sem elle, ficão reduzidas ao seo estado metallico sendo aquecidas, e formão o mesmo tempo o princípio radical das substâncias antigamente denominadas oxides metallicas.

Família Primeira: Iridio

Osmiete.......... Iridio Nativo ......I + Os

Família Segunda: Platina

Nativa ............Area de platina ..Pt

Platina negra

Família Terceira: Ouro

Nativo ........... Ouro Nativo ........Au

Tellurete........ Vea Graphica.....Ag ${ }^{2}+3 A u T 6$

Vea Amarella.....Ag $A T^{2}+2 P b T^{2}+8 A u T 3$

Família Quarta: Mercúrio

Nativo .............Mercurio Nativo.... Hg

Sulphurete .... Cinnabrio.............. HgS 2

Vea Hespática

Stinkzinobre

Muriatos....... Vea mercurial Cornea ...Hg $\bullet \bullet+2 \mathrm{M} \bullet \bullet$

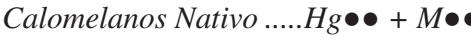

Família Quinta: Palladio

Nativo............ Palladio Nativo......Pa

Essa referência ao paládio traz a primeira proposta de símbolo para o mesmo, Pa, que mais tarde foi modificado para o que conhecemos hoje em dia, o Pd (os pontos "•" após o símbolo de alguns elementos indicam a existência de átomos de oxigênio enquanto " $M$ " se tratava do "radical muriático" que mais tarde foi modificado para ânion cloreto). São os trabalhos de Berzelius, aperfeiçoados com o passar do tempo, o cerne da simbologia que utilizamos até hoje para elementos químicos e seus compostos.

Em Portugal, o "Jornal de Coimbra" em seu volume VII do ano de 1814 publicou um artigo de Thomé Rodrigues Sobral, intitulado "Sôbre as difficuldades de uma boa anályse principalmente vegetal, para servir de resposta a uma pergunta que se faz ao autor" ${ }^{66}$ Sobral demonstra conhecimento sobre alguns elementos que teriam sido derivados a partir do trabalho dos minérios de platina:
A Platina he uma substância metallica, ainda que não vulgar, sobre a qual comtudo se-tem já escrito muito e trabalhado muito mais para descubrir a sua natureza ou como metal simples, ou como metal composto (...) Mas quanto não tem sido divididas as opiniões sobre a sua composição, e sobre o número dos metaes que o-compõem antes que se-chegasse á opinião hoje mais geralmente admitida, tendo-se levado successivamente de 4 até 12 metaes, que compõem a platina, ou pelo menos as suas minas.

$\mathrm{O}$ autor ainda indaga e reconhece a participação de Wollaston e Chenevix nos trabalhos sobre o minério de platina, mas não faz nenhuma alusão clara ao paládio.

\section{REFERÊNCIAS SOBRE O PALÁDIO NOS MEADOS DO SÉCULO XIX NO BRASIL: O AUXILIADOR DA INDÚSTRIA NACIONAL}

Em artigos ou periódicos produzidos no Brasil, o paládio só começou a chamar atenção nos meados do século XIX a partir de análises feitas em ligas metálicas ou em aplicações técnicas para o metal. Um dos mais importantes meios de comunicação nesse aspecto foi o periódico fundado em 1833 "O Auxiliador da Industria Nacional - ou collecção de Memórias e Noticias Interessantes", pelos membros da Sociedade Auxiliadora da Indústria Nacional, fundada em 1827. Com características claras do Iluminismo, o periódico tinha como objetivo: "promover por todos os meios ao seu alcance, o melhoramento e prosperidade da Indústria no Império do Brasil”, amalgamando os alicerces econômicos da nova nação com a produção de conhecimento científico. ${ }^{67}$

O Auxiliador foi um dos periódicos de maior espectro no século XIX, sendo publicado mensalmente no Rio de Janeiro, desde sua fundação em 1833, até o ano de 1892. Hoje o periódico está totalmente disponibilizado na plataforma on-line da Hemeroteca Digital da Biblioteca Nacional do Rio de Janeiro.

O primeiro artigo com referências ao paládio no Auxiliador foi uma tradução feita por Rochus (ou Roque) Schüch (1788-1844) que fez parte da comitiva austríaca que trouxe a Princesa Leopoldina, futura Imperatriz, para o Brasil em 1817. Ele assumiu o posto de bibliotecário e diretor do Gabinete de História Natural da Princesa e mais tarde foi um dos professores do Imperador Pedro II em disciplinas de alemão e ciências naturais. ${ }^{68}$ Schüch tinha conhecimentos em mineralogia e dois anos após sua chegada solicitou os direitos de mineração e produção de ferro nos arredores do Pico do Itabira e nas Serras de Aredes e da Moeda. ${ }^{69}$

$\mathrm{O}$ artigo de Schüch no Auxiliador, publicado no ano de $1837,{ }^{70}$ traz a tradução comentada do Mining Journal de Londres e aborda a "descoberta da fusão do ferro com ouro, que ultimamente, foi também descoberta nas fundições das Minas da Rússia", nos Montes Urais, cuja extração do ouro envolvia processos por via úmida com digestão ácida em grandes proporções. Schüch pretendia comparar essa nova metodologia com aquela que ele empregou em uma das fundições no distrito de Timbopeba, a cinco léguas de Ouro Preto, onde achou botões de ouro nas fornalhas que vertiam ferro após seu resfriamento. Ele percebeu que

na pedra de ferro oxidado de Minas Geraes existe igualmente huma porção de platina e de palladio, que fazem com que o ferro no acto da fundição esteja particularmente próprio para aço cementatorio.

Schüch julgava que a extração do ouro contido no minério de ferro poderia compensar a extração desse, utilizando-se das técnicas 
descritas para o minério russo o que, segundo ele, "compensaria bem as despezas da sua exportação para a Inglaterra".

Outro artigo também traduzido e publicado no Auxiliador é retirado do periódico francês "Journal des connaissances usuelles et pratiques", atribuído a Chaudat que ilustra uma série de ligas metálicas que poderiam ser úteis no Brasil. ${ }^{71}$ Uma delas traz a curiosa menção à utilização odontológica de uma liga de paládio, de forma semelhante à que ainda é utilizada atualmente:

Liga para os eixos dos dentes artificiaes

$$
\begin{aligned}
& \text { Platina........ } 40 \\
& \text { Prata...........60 }
\end{aligned}
$$

Outra liga para os dentes artificiaes

$$
\text { Palladio ........50 }
$$$$
\text { Prata............50 }
$$

Esta liga he mui importante; servem-se delia para fabricarem aquelles instrumentos de physica, que em outro tempo erão feitos de platina. Ella he de huma dureza e de huma côr superior á d'este ultimo metal, e comtudo não se oxida nas circumstancias ordinárias.

Liga para as molas de dentes artificiaes:

$$
\begin{aligned}
& \text { Palladio .......50 } \\
& \text { Prata............50 } \\
& \text { Cobre...........50 } \\
& \text { Ferro............50 }
\end{aligned}
$$

He huma liga muito util, possue huma elasticidade quasi igual a do aço, e reúne as vantagens de huma dureza e de uma leveza superiores à platina. Devemos a formação d'esta liga e da anterior a Mr. Parceval (sic), N. Jhonson (sic) de Londres.

O trecho acima é uma referência direta de Percival (e não Parceval) N. Johnson (e não Jhonson) que extraía o paládio do ouro extraído pela companhia inglesa responsável pela mina de Gongo Soco.

Outro interessante artigo do Auxiliador ${ }^{72}$ reafirma o antigo símbolo aplicado por Berzelius ao paládio (Pa e não Pd), além de atribuir sua massa em relação ao "peso" do oxigênio. Quem assina esse artigo é Pedro D'Alcântara Lisboa (1821 - 1885), membro da Sociedade Auxiliadora, formado pela Escola Central das Artes e Manufaturas de Paris $^{73}$ e que assinava os artigos como "Engenheiro Chimico". Na publicação o "equivalente químico" do paládio apresenta o valor de 665 que, através da referência de massa de oxigênio igual a 100, indicando uma massa molar equivalente a $106,4 \mathrm{~g} / \mathrm{mol}$, o mesmo valor considerado nos dias de hoje para essa propriedade do paládio.

No mesmo ano (1846), Alcântara Lisboa ainda assinou outros artigos nos números seguintes da revista e em um deles indica que o paládio tem uma forte identificação com o nosso país e comenta sobre a possibilidade de uma indústria de separação de metais nobres presentes no ouro que se produzia no Brasil:

e que o valor desses metaes monta a muitos milhões de francos, fácil é conceber a utilidade de separal-os no nosso paiz. Separando o Brasil esses metaes, poder-se-ha cunhar moedas com o palladio, moeda essencialmente nacional $e$ cujo valor intrínseco não pode ser contestado. ${ }^{74}$

Uma anônima e resumida tradução do texto em inglês do periódico "The Mechanics' Magazine" 75 traz uma aplicação para a proteção do ferro proposta por Robert Mallet (1810-1881) que utiliza a zincagem (proteção por zinco) e a paladiadura (proteção por paládio) em "um methodo para proteger com pouca despeza o ferro, e os outros metaes por meio do palladio; e torna-los tão inatacáveis pelo ar, e pela humidade como o mesmo palladio". O método consiste na limpeza da peça que será protegida por meio de sais de amônio, o que levava à retirada de material oxidado, e depois a peça tinha depositada uma camada de paládio "que se lhe applica no estado de amálgama com o mercúrio." O comentário final da metodologia, provavelmente adicionada à versão original por algum dos editores do Auxiliador, acrescenta ainda que "a protecção dada pelo palladio é tão efficaz como a do zinco; e como este metal é bastante vulgar entre nós, e hoje com nenhuma applicação, no Brasil deve-se a elle dar preferencia".

Apesar do que se disse em edições avulsas do Auxiliador, nenhum artigo abordava metodologias que tivessem sido propostas, testadas ou aplicadas em território nacional para a utilização do paládio. No entanto, no mesmo ano em que foi publicada a proteção do ferro, Frei Custódio Alves Serrão (1799-1873) - o quarto diretor do Museu Nacional entre o período de 1828 a 1847, após ter ocupado a carreira de lente de botânica, zoologia, química e mineralogia na Academia Militar $^{76}$ - publicou um artigo sobre o paládio em uma técnica que ele testara nos laboratórios do Museu. Enquanto esteve à frente desse, Serrão fez várias análises de minerais de diversas partes do Brasil que eram enviados ao gabinete de mineralogia do Museu. Suas atividades laboratoriais eram intensas pois recebia amostras de todo o Império e, na maior parte delas, a ilusão de riqueza dos coletores de minerais supostamente preciosos. Entretanto nas análises de Serrão quase nunca eram encontrados metais nobres como ouro, prata e platina em proporções satisfatórias. Serrão revela seu conhecimento da presença de platina e de paládio em Minas Gerais ao se queixar de que só de taes pratas e de taes platinas viessem amostras ao Museu, não lhe havendo sido nunca remettido nenhum só specimen do palladio nativo ou ligado ao ouro, tão abundante na lavra do Gongo como nenhum tão pouco da platina de Matto Grosso e de Minas Geraes. ${ }^{77}$

Em 30 de Maio de 1845, Serrão escreve ao Conselheiro de Estado, Ministro e Secretário de Estado dos Negócios do Império, José Carlos Pereira de Almeida Torres (o segundo Visconde de Macaé, 17991856) que a análise das prováveis amostras de platina de Camargos (MG) deu como resultado apenas a presença de ferro nativo. Aqui ele também se queixa que não recebeu nenhuma amostra de paládio e pouquíssimas amostras de ouro da lavra do Gongo Soco, indicando que deveria haver uma fiscalização imposta aos empresários de forma a relatar a presença de outros metais preciosos, enviando ao Museu em espécie (na própria matriz ou ganga) alguma parte dos pequenos direitos, a que estão sujeitos: os exames dessas espécies garanteria a exactidão dos pagamentos e serveria ao mesmo tempo para conhecermos a parte, que perdemos nos outros metais preciosos ou uteis, que os acompanhão, $e$ passam despercebidos. ${ }^{78}$

Após obter as amostras de ouro do Gongo Soco, Serrão pôde finalmente desenvolver uma metodologia da separação do paládio aurífero que foi publicada em 1847 no Auxiliador com as referências anteriores na seção Chimica, intitulado "Processo para separar o palladio dos outros metaes com que se acha ligado"..$^{79}$ Antes do trágico incêndio que vitimou o enorme acervo do Museu Nacional do Rio de Janeiro foi possível obter imagens de uma amostra de ouro paladiado de Gongo Soco (código MN 2661-M, Figura 5) além de sua análise em MEV-EDS feitas por responsáveis pelo Setor de Geologia (ver Informação Suplementar).

Frei Serrão deixa claro, logo no princípio de seu texto, que nunca havia conhecido o paládio nativo como anunciado por Wollaston, mas conhecia o metal a partir de sua composição em ligas de ouro das quais ele o separava. Sua metodologia de trabalho de separação dos metais se assemelhava à apresentada por Cloud em 1809, incluindo as etapas de inquartação das ligas de paládio, sua fusão com prata, granulação e ataque com ácido nítrico (Eq. 4). A solução (já sem a presença do ouro) ficava isenta da prata pela precipitação de $\mathrm{AgCl}$ após adição de ácido clorídrico ou de cloreto de sódio. A fração 




Figura 5. Fotografia de frente (a) e verso (b) da amostra MN 2661-M composta por pintas de ouro em uma matriz, de ferro e cromo; a amostra apresenta uma massa de 20,43g, dimensões de 30x35x8mm e composição entre 1 a $7 \%$ de paládio (ver Informação Suplementar a este artigo)

nítrica aquosa era então concentrada e novamente dissolvida com ácido sulfúrico para a conversão dos nitratos em sulfatos (Eq. 5). Essa diferença fundamental da ação do ácido sulfúrico no processo de Serrão tinha como finalidade

facilitar a reducção do palladio, e além disso de separar o iridio, platina, e rhodio, que por ventura se achem na dissolução nítrica... o que ha de particularmente meu neste processo é o meio que emprego para separar com economia este metal, o que não consegue o processo de Wollastton, nem o de Vauquelin, e só com grande perda e trabalho pretende alcançar o de Berzelius. ${ }^{79}$

Seu procedimento continua a ser relatado ao apontar que ele precipitava o paládio da solução resultante com ácido sulfúrico depois de adicionar pequenas lâminas ou fragmentos de zinco a quente (Eq. 6) em matrazes ou fiolas (recipientes de fundo chato semelhantes a erlenmeyers ou balões). É nessa etapa que ele procede à separação do cobre presente em pequenas quantidades a partir de repetidas lavagens da massa metálica reduzida. O paládio era então separado e martelado até a obtenção de um disco que Serrão fundia em cadinhos sob altas temperaturas. Outro detalhe interessante de sua técnica é o tratamento final do metal que, pela ação do ar que deveria produzir uma superfície oxidada e, dessa forma, assumia coloração azulada. Para evitar isso Serrão mergulhava os discos de paládio em sebo derretido, o que fazia com que a superfície do disco obtivesse uma coloração branca. Essa coloração também "se lhe pode dar pelo hydrogenio nascente, pondo os discos em contacto com fragmentos de zinco, água e ácido sulphurico".

$$
\begin{aligned}
& \mathrm{Au} / \mathrm{Pd} / \mathrm{Ag}_{(\mathrm{s})}+\mathrm{HNO}_{3(\mathrm{l})} \longrightarrow \mathrm{Pd}\left(\mathrm{NO}_{3}\right)_{2(\mathrm{aq})}+\mathrm{AgNO}_{3(\mathrm{aq})} \\
& \mathrm{Pd}\left(\mathrm{NO}_{3}\right)_{2(\mathrm{~s})}+\mathrm{H}_{2} \mathrm{SO}_{4(\mathrm{aq})} \rightarrow \mathrm{PdSO}_{4(\mathrm{aq})}+2 \mathrm{HNO}_{3(\mathrm{aq})} \\
& \mathrm{PdSO}_{4(\mathrm{aq})}+\mathrm{Zn}_{(\mathrm{s})}^{0} \rightarrow \mathrm{Pd}_{(\mathrm{s})}^{0}+\mathrm{ZnSO}_{4(\mathrm{aq})}
\end{aligned}
$$

Outra matéria anônima (ou que se possa atribuir ao novo redator do Auxiliador, Miguel Joaquim Pereira de Sá) é publicada em 1850 e indica aplicações para o paládio e suas ligas na forma de instrumentos de precisão, conforme aqueles produzidos na Europa, que compreendiam desde sextantes astronômicos a eixos de cronômetros. ${ }^{80} \mathrm{O}$ artigo ainda faz um comentário que ilustra o fato de que todo o paládio beneficiado na Europa fosse obtido do ouro paladiado brasileiro porque "a maior parte do nosso publico ignora as riquezas mineraes que seu paiz encerra, e a importância que estas riquezas podem ter para o futuro na sua indústria e commercio".

Em 1866, o redator da revista Frederico Leopoldo Cesar Burlamaque (1803-1866) foi o proponente de uma interessante forma de paladiar metais de forma moderna e que não utilizava amálgamas do metal, mas sim através de galvanoplastia. Para isso ele sugere a utilização de "dous ou três elementos da pilha de Buonsen (sic), e um banho para palladiar". ${ }^{81}$ A pilha de Robert Bunsen (1811-1899) foi criada em 1841 (pelo mesmo inventor do queimador a gás, ou bico de Bunsen) como opção mais barata às convencionais utilizadas à época por utilizar um eletrodo de carvão (Figura 6a) em substituição aos metais nobres empregados em outros componentes elétricos (pilhas, células e baterias).

Esse processo foi experimentado na Casa da Moeda e descrito da seguinte forma:

tome-se uma parte de chlorureto de palladio dissolvido e lance-se ammonia em excesso até redissolver o precipitado; junte-se uma meia parte de cyannureto de potássio, ferva-se e filtre-se. Este banho não é bastante energico empregado a frio; juntando se porém a acção da pilha uma temperatura de 70 a 80 gráos, o resultado é excellente, e o palladio adhere perfeitamente a peças que se galvanisa, tomando esta o aspecto daquelle metal, e conservando a propriedade de se não oxidar. ${ }^{81}$

No restante do século XIX algumas outras poucas referências ainda trariam novas propriedades do paládio, no entanto, sem dar nenhum destaque a sua descoberta ou mesmo sobre a existência desse metal em forma nativa no Brasil

\section{REFERÊNCIAS AVULSAS EM OUTROS PERIÓDICOS E LIVROS BRASILEIROS DOS MEADOS DO SÉCULO XIX SOBRE O PALÁDIO}

O periódico "O Guanabara: Revista Mensal Artística, Scientífica e Litteraria", também com cunho científico, noticiou em sua primeira edição de $1850^{83}$ as "Analyses feitas por ordem do Sr. Ministro da Fazenda" de moedas cunhadas no período de Dom João VI, além das moedas cunhadas entre 1847 a 1849. O artigo é assinado por dois autores, "Azeredo Coutinho e Capanema" provavelmente o primeiro se trate de Cândido de Azeredo Coutinho, ?-1878, o "medalheiro 


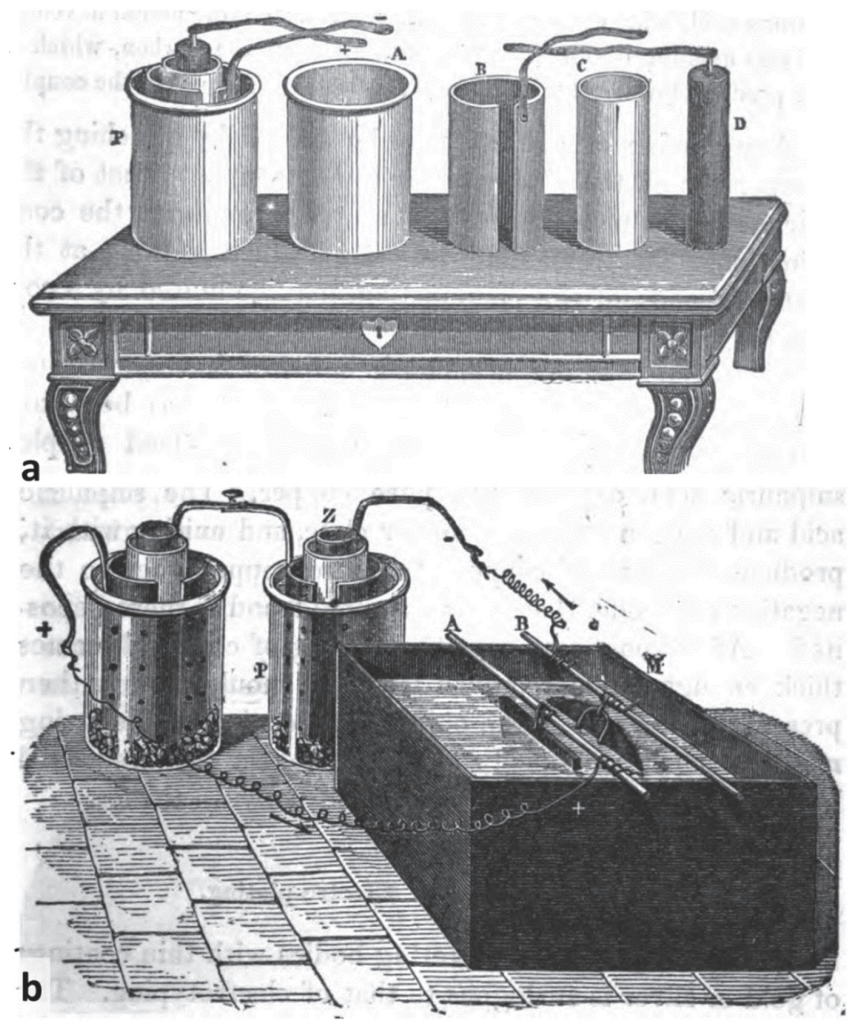

Figura 6. a) Elementos da pilha de Bunsen (A: frasco de vidro ou cerâmica com solução diluída de ácido sulfúrico; B: um cilindro de zinco; $C$ : frasco poroso; D: cilindro de carvão e contatos metálicos de cobre); b) aplicação da bateria em um processo de galvanização ${ }^{82}$

da Casa da Moeda do Rio" e o naturalista e engenheiro Guilherme Schüch Capanema (1824-1908, filho do já citado Roque Schüch). Nesse trabalho se revela mais uma análise de abertura de amostras de ouro com através do uso de água-régia, seguida do conjunto de métodos de evaporação de excesso dos ácidos, separação da prata por adição de cloreto e adição do agente redutor ácido oxálico para precipitação do ouro. Após a separação desse último, os ensaístas precipitavam com "ácido thionhydri em estado de sulfureto os metaes que ainda estavão na dissolução, e que por este meio supportão essa transformação". Para a análise do paládio se fazia precipitar o metal com a adição de cianeto de mercúrio da mesma forma como foi feito por Wollaston. Os resultados indicavam, além do ouro, apenas a presença de paládio e ferro sem indicação de suas proporções exatas.

O paládio brasileiro ganhou destaque em Exposições Universais que foram realizadas por países de todo o mundo. Nas edições em que teve participação (a partir da exposição de Londres de 1862), o Império do Brasil passou a enviar matérias primas e produtos derivados das áreas de agricultura, artes, antropologia, indústria e mineração. O objetivo dessas participações era impulsionar a mineração nacional que, durante esse período, estava em declínio por falta de investidores ${ }^{84}$ além de servir como uma vitrine de novidades abertas a um público grande e diversificado.

Em 1867, na Exposição Universal de Paris, o relatório de Julio Constâncio de Villeneuve feito para o Imperador Dom Pedro II ${ }^{85}$ apresentava o destaque que foi dado ao pavilhão (Figuras 7 a e $7 \mathrm{~b}$ ), que expunha moedas e medidas dos diversos países participantes:

Percorramos agora a Exposição Brazileira, partindo do Jardim central. No kioske elevado no meio d'este Jardim, $e$ destinado as moedas, pesos e medidas, achava-se uma collecção completa das moedas brazileiras, padrões dos pesos das moedas nacionaes feitos de liga de palladio e prata, $e$ outros do peso da moeda de $2 \$ 000$ feitos de palladio puro, expostos pela casa da moeda da Côrte.

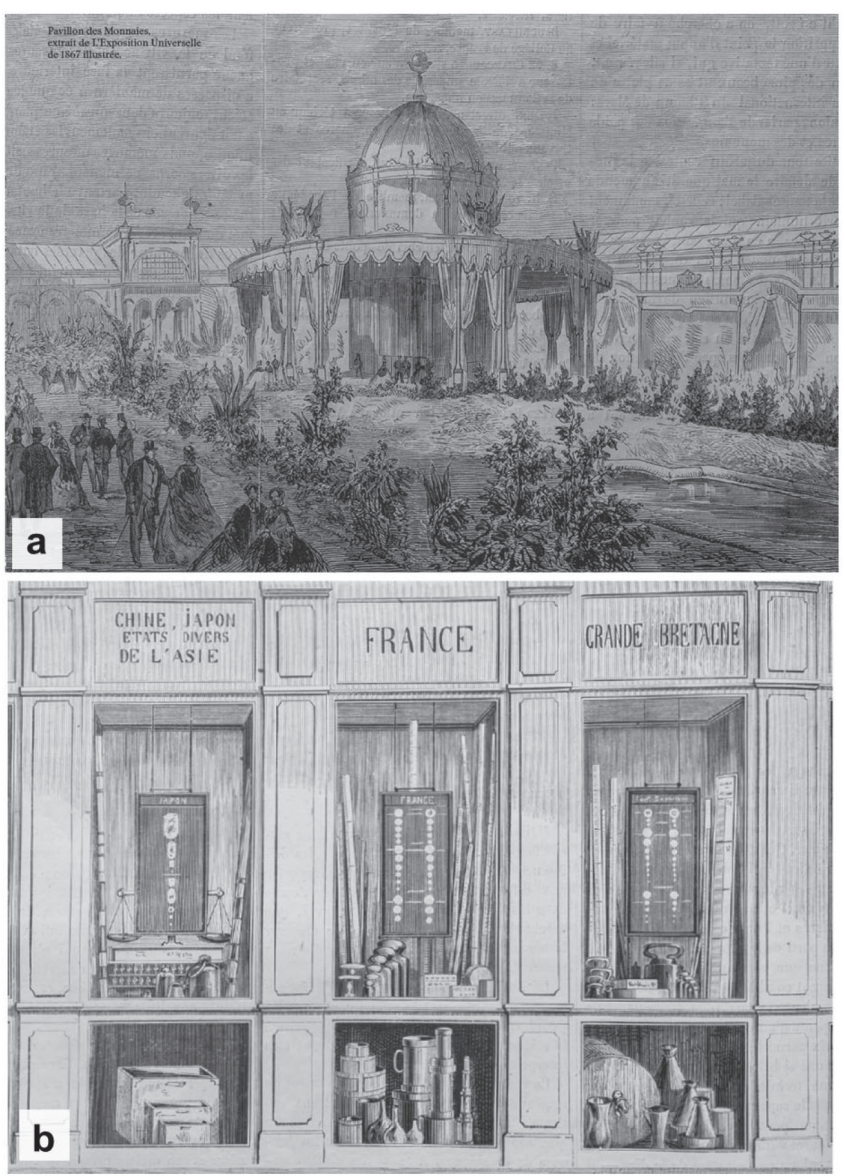

Figura 7.a) Pavilhão ou "kiosk" central da Exposição Universal de Paris e b) exposição de moedas, pesos e medidas de vários países dispostas em vitrines ${ }^{86}$

Villeneuve ainda menciona a menção honrosa conquistada por Azeredo Coutinho junto à exposição da classe 40 de minerais e derivados. Na edição seguinte, a Exposição Mundial de Viena de 1873, foram apresentadas barras, discos e fios de paládio, mais uma vez trazidos pelo responsável pela Casa da Moeda, Cândido de Azeredo Coutinho, vencendo dessa vez a medalha de mérito dentre os expositores do $1^{\circ}$ Grupo de "Lavra de minerais e metalurgia". 87

\section{REFERÊNCIAS DO SÉCULO XVIII E XIX RELACIO- NADAS AO PALÁDIO E/OU A PLATINA NO BRASIL}

Apesar de o paládio ter sido descoberto no início do século XIX, algumas notícias sobre achados de platina nativa ou ligas de ouro, cuja presença e proporção de outros metais alteravam suas propriedades, foram feitas no Brasil no século XVIII e foram ainda registradas até o princípio do século XIX. Algumas dessas notícias podem estar relacionadas ao paládio pois para muitos exploradores um elemento metálico branco e não identificado poderia se passar por prata ou platina, os únicos conhecidos até então.

Nos documentos e cartas obtidas por Orville A. Derby (18511915), que tratavam sobre as primeiras referências ao descobrimento do ouro em Minas Gerais, ${ }^{88}$ a busca por minerais e metais preciosos revelavam, além do ouro, a prata e esmeraldas na serra do Sabarabuçu que se tornaram lendárias mesmo na Europa ainda no século XVII. Derby reproduz o conteúdo da carta patente obtida em 1698 por Manuel de Borba Gato, que fazia saber 
aos que esta minha carta-patente virem que havendo respeito ao muito que convém ao serviço de sua magestade que D. G. e ao bem commum desta capitania e das da repartição do Sul que se descobram minas a cujo negocio me mandou o dito senhor a estas partes, e pelas noticias que tenho que na paragem a que chamam Sabarabussú haverá mina de prata, a cujo descobrimento mando Manoel de Borba Gato para que com sua actividade e zelo que mostra no serviço d'el-rei Nosso Senhor explore os morros e serras que houver naquellas partes

Derby acredita que as descobertas de prata estivessem relacionadas à existência de paládio "que se apresenta frequentemente na região de Sabará e em que uma mistura com o ouro de uma pequena quantidade do metal palladio dá á liga uma côr esbranquiçada". É conveniente lembrar que o óxido de paládio dá ao ouro uma coloração escura do "ouro preto", ao contrário do paládio metálico que em ligas naturais forma a coloração clara do "ouro branco". Em outro documento datado de 1700, escrito por Pedro Taques de Almeida e reproduzido por Derby em seu artigo, uma curiosa descrição do achado de ouro, que para Derby não restava sombra de dúvida tratar-se da descrição do ouro paladiado de Minas:

O tenente-general Manoel do Borba Gato trouxe agora ao general Arthur de Sá e Meneses umas folhetas limitadas que parece foram douradas, que me certificou o dito general, era prata achada entre ouro das quebradas, em que alguns dos serros daquelle território afocinham, porque raspando o dourado mostra prata, e neste mesmo sitio se descobriu ouro que os mineiros lhe puseram o nome de prateado, porque é mais prata que ouro; razão porque o não lavraram por não ter valor; e sem mineiro será difficil descobrir-se prata

Outra interessante referência sobre ligas de ouro é feita pelo jesuíta italiano Antonil (André João Antonil, 1649-1716) em seu livro "Cultura e opulência do Brazill" de $1711 .{ }^{89}$ No livro são descritas as drogas e minas (minerais) do país por meio de várias "notícias curiosas". Quando descreve as diversas qualidades do ouro descoberto em ribeirões de Minas Gerais, Antonil relata que:

O ouro finalmente do ribeiro do Itatiaja, he de côr branca, como a da prata, por não estar ainda bem formado, como dissemos acima, e deste se faz pouco caso, posto que alguns digão, que indo ao fogo ás vezes por mais formado, foi mostrando cor amarela.

É provável que Antonil esteja descrevendo algum pequeno rio da Serra do Itatiaia que faz divisa entre as atuais cidades de Ouro Preto e Ouro Branco, fato que talvez tenha dado nome a esse segundo município. Já em Ouro Preto o termo "ouro podre", que foi utilizado por Berzelius na análise da liga paladiada, batizava um dos Morros da cidade, desde o início do século XVIII, mas que hoje é denominado Morro da Queimada.

No livro das "Memórias sobre as minas da Capitania de Minas Geraes" de José Vieira Couto (escrito em 1801 e divulgado em 1842),${ }^{90}$ esse naturalista descreve um inusitado fato ocorrido na Casa de Intendência e Fundição de Sabará, hoje o Museu do Ouro do município. Fazia 20 anos, de acordo com a descrição de Couto, que um homem levara até aquela fundição uma amostra de metal branco, "ignorando o que seria" sua natureza ou composição. Apresentou a amostra ao fundidor da casa para que realizasse análises que procedeu com a tentativa de fundi-la na intenção de fazer um lingote, conforme se trabalhava com o ouro. Gastou muito tempo e muito solimão $\left(\mathrm{HgCl}_{2}\right)$ para esse trabalho e ao final do processo, quando tentou imprimir no lingote as marcas de cunhagem a barra se quebrou em diferentes partes, em uma tentativa provavelmente feita pela prensa que ainda se encontra no museu (Figura 8). Ainda nas palavras de Vieira Couto:

Vendo o tal fundidor um metal de tão dificil fusão, tão rachadiço, de côr esbranquiçada, e tão remota da do ouro, assentou sem nenhum escrupulo não só não ser ouro, mas nem menos outro qualquer metal, que podesse ter algum prestimo ou valor... Então lhe explicou o tal dono, que assim sempre o esperára, vista a sua abundancia, e que na paragem podia elle carregar cavallos: foram suas palavras: deu costas, $e$ deixou a barra. Existe esta barra ainda hoje no cofre da dita Intendencia de Sabará: poderá ter de 30 para 10 oitavas de pezo, segundo indica o seu tamanho. Tirei. d'ella um pequeno pedaço, que o examinando achei ser platina com uma quinta parte de ouro.

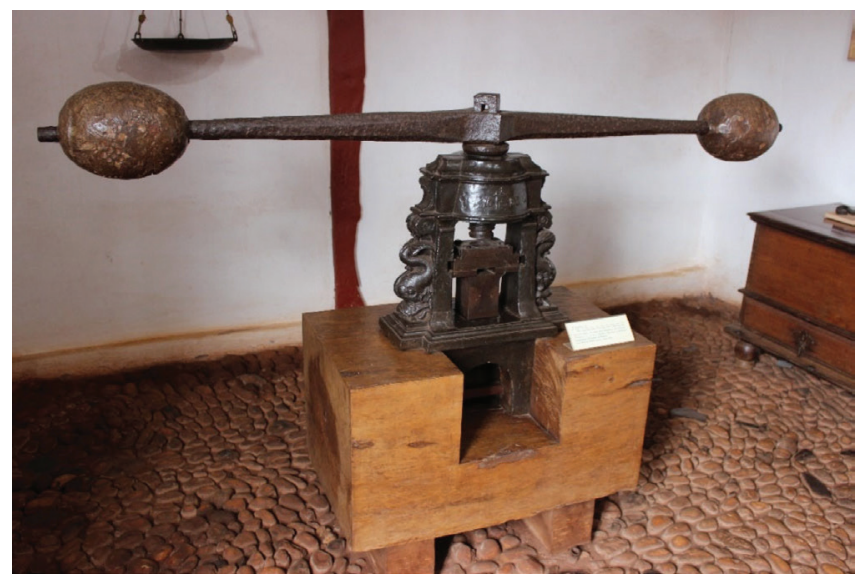

Figura 8. Prensa utilizada na Casa de Intendência e Fundição de Sabará para cunhar o selo da Coroa Portuguesa em barras e lingotes de ouro do Museu do Ouro, Sabará. Foto do autor LEF

Vieira Couto descreveu não só o descobrimento de uma liga de ouro com algum metal branco mas também afirmou, sem apontar que teria feito alguma análise, que a mesma deveria se tratar de platina. Couto escreveu seu livro antes do descobrimento do paládio e provavelmente não tinha conhecimentos para testar sua presença na amostra da barra que conseguiu na Casa de Fundição de Sabará (que atualmente não mantém registros de bens que circularam durante o período do ouro em seus arquivos). Couto ainda avalia que os responsáveis pelas instituições governamentais eram desmazelados e ignorantes quanto às possibilidades de utilização e valores associados a materiais diferentes daqueles que os fundidores estavam acostumados a lidar, fazendo com que registros da fonte desse metal fossem para sempre perdidos. Por outro lado, Couto indica a localização de pontos onde se encontravam a platina como resultado de suas viagens aos Sertões do Rio Abaeté:

Os logares hoje conhecidos nesta Capitania, onde se extrahe ou existe a platina, são na Comarca do Serro Frio, este mesmo Córrego das Lageas e suas visinhanças; na Comarca da Villa Rica, em algumas lavras da Itabira; na Comarca de Sabará, em a Nova Lorena Diamantina.

A localização da platina da Nova Lorena Diamantina é indicada em um mapa referente à viagem de Vieira Couto até o Sertão do Abaeté onde encontrou o veio de galena argentífera do qual havia sido incumbido de avaliar. ${ }^{91}$

O naturalista de Tijuco ainda foi responsável pela análise de outra amostra de platina em 1807 que se lhe fez analisar pelo governador da Capitania Pedro Maria Xavier de Ataíde e Melo. Na carta ${ }^{92}$ que 
escreve o Intendente Geral dos Diamantes, Modesto Antônio Mayer, descreve esse que recebera de José Soares Pereira "humas folhetas de Metal branco, muito pezado para a sua grandeza, me disse que o Sugeito, que lhas havia confiado lhe pediu, quisesse fazer examinar". Couto assegurou tratar-se de platina, o que muito agradou ao intendente, que enxergava no achado "um manancial de riqueza Nacional".

Ainda no princípio do século XIX, o mineralogista inglês John Mawe (1764-1829) visitou as minas de ouro e diamantes de Minas Gerais entre os anos de 1809 e 1810 deixando um mapa detalhado de seu percurso desde o rio Paraíba, no estado do Rio de Janeiro, até o "distrito diamantino". Mawe descreve ${ }^{93}$ uma curiosa descoberta em um córrego entre Itambé e Gaspar Soares:

Sem qualquer ocorrência importante, chegamos a um lindo riacho, perto do qual havia uma cabana miserável, onde duas mulheres teciam algodão. Este lugar, aparentemente tão insignificante, provou ser um dos mais interessantes, em um ponto de vista mineralógico, que eu tinha visitado até agora. É chamado Largos, e também tem o nome de Oro Branco, em alusão a uma substância granular, não muito diferente do ouro em tamanho e peso, encontrada em uma lavagem de ouro no leito da correnteza. Esta substância, que desde então provou ser platina, foi descoberta há muitos anos no cascalhão abaixo da terra vegetal, e compete à rocha sólida, acompanhada de ouro e óxido de ferro escuro. Nessas circunstâncias, o povo julgou ser ouro unido com algum outro metal, do qual não poderia ser separado; $e$, como a quantidade de ouro real encontrada era pequena, e o ouro branco, como eles o chamavam, não era conhecido como valioso, o trabalho foi gradualmente sendo negligenciado $e$, finalmente, abandonado. Procurei um exemplar da substância: apareceu acompanhado de ósmio e irídio, e estava em grãos mais ásperos do que a platina trazida da província do Choco; Essa última circunstância pode ser devido à não ter sido triturada com mercúrio. Agora que a substância é conhecida como platina, é duvidoso que o trabalho possa ser retomado com vantagem, já que a demanda por esse artigo é tão pequena, que a quantidade vendida dificilmente pagaria as despesas. Perto deste existe uma mina chamada Mata Cavalhos (sic).

Apesar de mencionar a presença de ósmio e irídio - dois metais anteriormente descritos como componentes das ligas de platina das províncias espanholas, Mawe não dá nenhuma indicação a respeito da composição em paládio das amostras que recolhe. A atribuição que ele dá sobre nomes de locais e de rios também não é correta. É provável que Mawe tivesse encontrado a platina no Córrego das Lages (sendo assim, nem "Córrego das Lageas" ou "Córrego dos Largos" como Vieira Couto e Mawe respectivamente denominaram), a norte de Morro do Pilar (antiga Gaspar Soares), córrego que desagua no Rio Santo Antônio que é próximo à fazenda Mata Cavalos, todos esses encontrados entre os municípios de Conceição do Mato Dentro e Morro do Pilar (Figura 9).

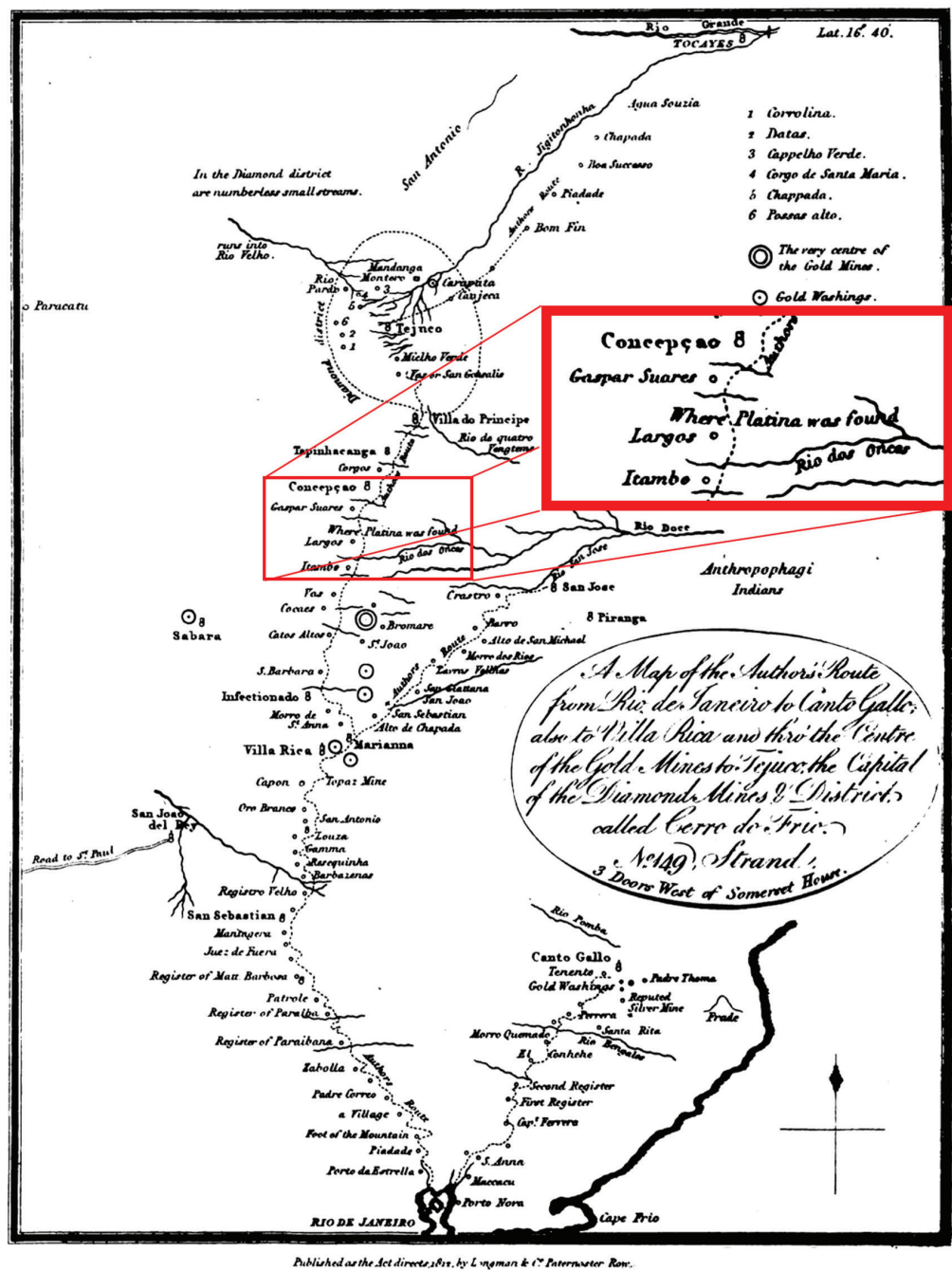

Figura 9. Mapa da viagem de Mawe por Minas Gerais entre os anos 1809-1810 com destaque ao local 'onde a platina foi encontrada'94 
A cronologia da descoberta da platina também é descrita pelo Barão de Eschwege em seu livro, Pluto Brasiliensis, ${ }^{95}$ no qual indica que tal metal havia sido descoberta pela comissão da qual fazia parte o "Dr. Couto" nos sertões do Abaeté entre 1800 e 1805 e que apenas depois disso a platina teria sido descoberta nos arredores de Conceição de Mato Dentro. Eschwege não leva em consideração a informação da amostra de platina de Sabará, contida na mesma obra de onde deve ter obtido as informações escritas por José Vieira Couto.

\section{CONSIDERAÇÕES FINAIS}

Apesar do que alguns autores brasileiros possam afirmar, a descoberta do paládio como novo elemento químico não teve princípio com amostras originadas do Brasil ou, mais especificamente, de Minas Gerais. Antes mesmo das referências sobre platina no nosso país, esse metal e componentes do mineral de platina já despertavam a aguçada curiosidade de cientistas de renome na Europa por meio do extravio e contrabando dos bens minerais das colônias espanholas. Contudo, a descoberta do paládio nativo, como descrito por W. Wollaston em 1809, encrustado em minério de platina, resolveria por vez as discussões acerca da controvérsia gerada por sua descoberta com demais pesquisadores contemporâneos. A partir disso foi possível a separação e o estudo particular do metal, que despertou grande interesse econômico dada as suas particulares características.

O ouro extraído por ingleses em Minas Gerais foi, com certeza, a maior fonte de paládio que, na forma de ligas com o ouro, foi explorado durante o século XIX até a descoberta de novas minas paladíferas nos Montes Urais na Rússia. É ainda durante aquele século que as principais publicações nacionais davam destaque ao novo metal, divulgando as vantagens e sua provável utilização em virtude das "inesgotáveis" fontes de seus minerais em Minas Gerais. Temos de certo apenas que o metal foi usado no Brasil para a cunhagem de moedas e na produção de medidas oficiais e equipamentos que ganharam notoriedade em exposições mundiais.

Por fim, é interessante notar o "amálgama" formado por ouro, platina e paládio - e em citações mais antigas com a prata - em documentos e livros escritos anteriormente à descoberta do paládio em textos produzidos no Brasil nos séculos XVIII e início do século XIX.

\section{MATERIAL SUPLEMENTAR}

A resposta à solicitação de acesso à amostra MN 2661-M (Paladio com Ouro) está disponível em http://quimicanova.sbq.org.br na forma de arquivo PDF, com livre acesso.

\section{REFERÊNCIAS}

1. Zampieri, M. C. T.; Identificação dos Elementos do Grupo da Platina oriundos da emissão veicular, utilizando as folhas de Tibouchina granulosa (Desr.) Cong. (Melastomataceae) como biomonitor de material particulado (MP) provenientes de emissão de catalisadores veiculares na Região Metropolitana de São Paulo (RMSP), Tese de Doutorado, IPEN - USP, São Paulo, 2017.

2. Ricciardi, O. P.; Metais do Grupo da Platina. Sumário Mineral do Departamento Nacional de Produção Mineral (DNPM), 2014.

3. http://www.platinum.matthey.com/prices/weekly-price-bulletins-archive, acessada em fevereiro de 2019.

4. Cabral, A. R.; Lehmann, B; Tupinambá, M.; Schlosser, S.; KwitkoRibeiro, R.; de Abreu, F. R.; Econ. Geol. 2009, 104, 1265.

5. Cabral, A. R.; Lehmann, B; Tupinambá, M.; Wiedenbeck, M.; Brauns, M.; J. Geochemical Exploration 2011, 110, 260.
6. Cabral, A. R.; Radtke, M.; Munnik, F.; Lehmann, B; Reinholz, U.; Riesemeier, H.; Tupinambá, M.; Kwitko-Ribeiro, R.; Chem. Geol. 2011, $281,125$.

7. Cabral, A. R.; Zeh, A.; Galbiatti, H. F.; Lehmann, B.; Econ. Geol. 2017, 110,263

8. Guerra, M. F. J.; Archeol. Sci. 2004, 31, 1225.

9. http://www.bcb.gov.br/htms/museu-espacos/pepitas/HistoriaSPelada. asp?idpai=, acessada em fevereiro de 2019.

10. Hussak, E.; Sitzungsber. Akad. Wiss. Wien Math.-Naturwiss. Kl. 1904, 113, 379 .

11. Hussak, E.; Annaes da Escola de Minas de Ouro Preto 1906, 8, 75.

12. Obras várias de Virgil von Helmreichen (1805 - 1852) - contribuições à geologia do Brasil; Renger, F. E., org.; Fundação João Pinheiro, Centro de Estudos Históricos e Culturais: Belo Horizonte, 2002.

13. A História da Escola de Minas; Lemos, P., org.; Ed. Graphar: Ouro Preto, 2012

14. Marciano, V. R. P. R. O.; UFMG Diversa, Revista da Universidade Federal de Minas Gerais, 2007, 5. Disponível em https://www.ufmg. br/diversa/11/artigo4.html, acessada em fevereiro de 2019.

15. Guimarães, D.; Boletim da Sociedade Brasileira de Geologia, 1958, 7, 2.

16. Weeks, M. E.; Leicester, H. M.; Discovery of the Elements, $7^{\text {th }}$ ed., Mack Printing Company: Easton, 1968.

17. Ulloa, A. Em A general collection of the best and most interesting Voyages and Travels in all parts of the World; Pinkerton, J., org.; Longman, Hurst, Rees, Orme, and Browns, Paternoster-Row: Londres, 1813.

18. Wollaston, W. H.; Phil. Trans. of the Royal Society of London, 1797, 87, 386.

19. McDonald, D.; Platinum Metals Reviews 1967, 11, 18.

20. Lennartson, A.; Nat. Chem. 2014, 6, 746.

21. Tennant, S.; Philos. Trans. R. Soc. London 1797, 87, 219.

22. Griffith, W. P.; Platinum Metals Reviews 2003, 47, 4.

23. Vallvey, L. F. C.; Ann. Sci. 1996, 53.

24. Leonardos, O. H.; Geociências no Brasil, a contribuição britânica, Fórum Editora: Rio de Janeiro, 1970. p. 32.

25. Tennant, S.; Philos. Trans. R. Soc. London 1804, 94.

26. Wollaston, W. H.; Philos. Trans. R. Soc. London 1804, 94.

27. Griffith, W.; Platinum Metals Reviews 2003, 47, 175.

28. Usselman, M. C.; Ann. Sci. 1978, 35, 551.

29. Chenevix, R.; Philos. Trans. R. Soc. London 1803, 93, 290.

30. Griffith, W. P.; Morris, P. J. T.; Notes Rec. R. Soc. London 2003, 57, 299.

31. Anônimo; Journal of Natural Philosophy, Chemistry, and Arts 1804, 7.

32. Wollaston, W. H.; Philos. Trans. R. Soc. London 1805, 95, 316.

33. Chenevix, R.; Philos. Trans. R. Soc. London 1805, 95, 104.

34. Accum, F.; System of Theoretical and practical Chemistry - in two volumes with plates, Kimber \& Conrad: Philadelphia, 1808, Vol. II.

35. Wollaston, W. H.; Philos. Trans. R. Soc. London 1809, 99, 189.

36. Silva, L. A. R.; Quadro elementar das relações politicas e diplomáticas de Portugal com as diversas potencias do mundo, desde o principio do XVI século da Monarchia Portugueza até aos nossos dias. Tomo Décimo Oitavo. Typographia da Academia Real de Sciencias: Lisboa, 1860.

37. Carvalho, D. C. A. B. M.; Domingos Antônio De Sousa Coutinho (1760-1833): Trajetória de um diplomata Português. Em Anais do $3^{\circ}$ Seminário Nacional de História da Historiografia: aprender com história? EdUFOP: Ouro Preto. 2009.

38. Sowerby, J.; Exotic Mineralogy: or, coloured figures of foreign minerals, as a supplement to British Mineralogy, Benjamin Meredith: London, 1811.

39. RSE (Royal Society of Edimburgh); Biographical Index of Former Fellows of The Royal Society Of Edinburgh 1783 - 2002, part II. K-Z, Edimburg, 2006.

40. Murray, J.; A system of Chemistry, Longman, Hurst, Rees \& Orme: Edinburg, 1809, Vol. III. 
41. Cloud, J.; Trans. Am. Philos. Soc. 1809, 6, 407.

42. Gehlen, A. F.; Schweiggers Journal für Chemie 1811, 1, 362.

43. Johnson, P. N.; Philos. Mag. 1812, 40, 3.

44. McDonald, D.; Hunt, L. B.; A History of platinum and its allied metals, Johnson Matthey, Hatton Garden: London, 1982.

45. Lassaigne, J. L.; Journal de Chimie Médicale, de Pharmacie, de Toxicologie et Revue des Nouvelles Scientifiques Nationales et Étrangères, Tome IX, II serie, 1842.

46. Wilhelm August Lampadius (1772-1842); Nature 1942, 149, 409.

47. Lampadius, W. A.; Plattner, G. P.; Journal für Technische und Ökonomische Chemie 1833, 18, 353.

48. http://tu-freiberg.de/universitaet/profil/geschichte-6, acessada em fevereiro de 2019.

49. Jedwab, J.; Cassedanne, J.; The Canadian Mineralogist 1998, 36, 887.

50. Berzelius, J. J.; Jahres-Bericht über die Fortschritte der physischen Wissenschaften 1835, 15, 205.

51. Oki, M. C. M.; Quim. Nova 2009, 32, 1072.

52. Pohl, J. E.; Viagem no interior do Brasil; Amado, M., Amado, E., trad.; Editora Itatiaia: Belo Horizonte, 1976, pp. 136 e 277.

53. Nekrasov, I. Y.; Geochemistry, Mineralogy and Genesis of Gold Deposits, CRC Press: Boca Raton, 1996, p. 323.

54. https://www.mindat.org/min-10923.html, acessada em fevereiro de 2019.

55. Roeser, H. M.; Schürmann, K.; Terrae Didática 2015, 11, 14.

56. Lampadius, W. A.; Journal für Praktische Chemie 1837.

57. Rose, G.; Nature 1873, 8, 277.

58. Rose, G.; Poggendorf Annalen der Physik 1842, 55, 329.

59. Seamon, W. H.; The Chemical News and Journal of Physical Science 1882, 46, 216.

60. Kemp, J. F.; Bulletin of the United States Geological Survey 1902, 193, 61.

61. Reis, F. J. E.; Os periódicos Portugueses de Emigração (1808-1822): as ciências e a transformação do país. Tese de Doutorado em História e Filosofia das Ciências da Universidade Nova de Lisboa, Lisboa, 2007

62. Correio Braziliense 1813, 10.

63. Correio Braziliense 1813, 11.

64. O Investigador Português em Inglaterra 1817, 74, 203.

65. O Investigador Português em Inglaterra 1818, 81, 185.

66. Sobral, T. R.; Jornal de Coimbra 1814, 7, 36.

67. Barreto, P. R. C.; Sociedade Auxiliadora da Indústria Nacional: Oficina de homens. Anais do XIII Encontro de História ANPUH-Rio, Rio de Janeiro, 2008; idem: Sociedade Auxiliadora da Indústria Nacional: o templo carioca de Palas Atena, Tese de doutorado, Rio de Janeiro, HCTE, UFRJ. 2009.

68. Calmon, P.; O Rei Filósofo - vida de D. Pedro II. Cia. Editora Nacional: São Paulo - Rio de Janeiro - Recife - Porto Alegre, 1938, pp. 52 e 54.

69. RAPM - Revista do Arquivo Público de Minas 1901, 6, 137.

70. Schüch, R.; O Auxiliador da Indústria Nacional 1837, 5, 299.

71. Anônimo; O Auxiliador da Indústria Nacional 1843, 1, 147.
72. Lisboa, P. A.; O Auxiliador da Indústria Nacional 1846, 1, 9.

73. Filgueiras, C. A. L.; Origens da Química no Brasil, Editora Unicamp Sociedade Brasileira de Química: Campinas, 2015, pp. 257-260.

74. Lisboa, P. A.; O Auxiliador da Indústria Nacional 1846, 14, 9.

75. Mallet, R.; The Mechanics' Magazine 1842, 36, 39.

76. Filgueiras, C. A. L.; Origens da Química no Brasil, Editora Unicamp Sociedade Brasileira de Química: Campinas, 2015, p. 252.

77. Netto, L.; Investigações históricas e scientíficas sobre o Museu Imperial e Nacional do Rio de Janeiro, Instituto Philomático: Rio de Janeiro, 1870, p. 86.

78. RAPM - Revista do Arquivo Público de Minas Gerais 1898, 3, 758.

79. Serrão, C. A. P.; O Auxiliador da Indústria Nacional 1847, $2,165$.

80. Anônimo; O Auxiliador da Indústria Nacional 1850, 4, 138.

81. Anônimo; O Auxiliador da Indústria Nacional 1866, 1, 116.

82. Peck, W. G.; Introductory course of Natural Philosophy for the use of schools and academies, Barnes \& Burr: New York, 1865.

83. Capanema, G. S.; Coutinho, A. C.; O Guanabara 1850, 1, 31.

84. Santos, P. C. M.; O Brasil nas Exposições Universais (1862 a 1911): mineração, negócio e publicações, Dissertação de mestrado apresentada ao Instituto de Geociências da Unicamp, Campinas, 2009.

85. Villeneuve, J. C.; Relatório sobre a Exposição Universal de 1867. Tomo primeiro. Typographia de Julio Claye: Paris, 1868, p. 62.

86. Numismatic Auction, Napoleon III, Numismática de Mônaco: Mônaco, 2017.

87. Relatório da Commissão que representou o Império do Brasil na Exposição Universal de Vienna na Áustria em 1873, Typographia Nacional: Rio de Janeiro, 1874, p. 23.

88. Derby, O. A.; Revista do Instituto Histórico e Geographico de São Paulo 1900, 5, 279.

89. Antonil, A. J.; Cultura e opulência do Brasil, Editora Itatiaia: Belo Horizonte, 1982.

90. Couto, J. V.; Memórias sobre as minas da Capitania de Minas Geraes - suas descripções, ensaios, e domicilio proprio, Ed. Laemmert: Rio de Janeiro, 1842, p. 14.

91. Faria, L. E.; Filgueiras, C. A. L.; Quim. Nova 2019, 42, 105.

92. APM - Arquivo Público Mineiro. Informação de serviço que faz o intendente geral dos diamantes sobre a extração de uma pedra de oitava, que a princípio foi avaliada com duzentas oitavas mais de ótimos diamantes, e que depois sendo a mesma examinada por José Vieira Couto, este disse, que não passava de uma pedra de platina. SG-CX 70, DOC 15. Tejuco, 18/04/1807.

93. Mawe, J.; Travels in the interior of Brazil, Longman, Hurst, Rees, Orme, and Browns, Paternoster-Row: Londres, 1812. p. 209

94. Mawe, J.; Travels in the interior of Brazil, Longman, Hurst, Rees, Orme, and Browns, Paternoster-Row: Londres, 1812, p. 136.

95. Eschwege, W. L.; Pluto Brasiliensis; Murta, D.; trad.; Ed. Itatiaia: São Paulo, 1979, p. 166. 